\title{
MACROECONOMIC EFFECTS OF MINIMUM WAGE INCREASES IN AN ECONOMY WITH WAGE UNDERREPORTING
}

\author{
ANASTASIIA ANTONOVA ${ }^{\text {ab * }}$ \\ ${ }^{a}$ National Bank of Ukraine \\ Email: Anastasiia.Antonova@bank.gov.ua \\ ${ }^{b}$ Kyiv School of Economics \\ Email: aantonova@kse.org.ua
}

\begin{abstract}
I have built a monetary DSGE model to investigate how wage underreporting in an economy characterized by a minimum wage regime affects the macroeconomic response to a minimum wage increase. The model is calibrated and estimated for Ukraine. The main result is that under a higher degree of wage underreporting, the economy is less responsive to a minimum wage shock. Quantitatively, the magnitude of the response to a minimum wage shock is affected by the share of non-Ricardian households, that is, households that do not have access to financial markets and consequently consume all of their income each period.
\end{abstract}

JEL Codes

E24, E26, J31, J46

Keywords minimum wage, wage underreporting, shadow economy, DSGE, non-Ricardian households, New-Keynesian models

\section{INTRODUCTION}

Since 2017, the Ukrainian government adopted several substantial raises of the legal nominal minimum wage. In 2017, the legal minimum wage was increased by approximately $132 \%$ (comparing to the previous year), in 2018 - by $16 \%$.

The main aim of the government in increasing the minimum wage is to ensure decent living standards for low-income working Ukrainians. However, since Ukrainian economy is characterized by a large degree of wage underreporting, the other goal of raising the minimum wage is to increase tax revenues.

In countries where the detection of tax evasion is not perfect, some firms tend to reduce their tax and social security contributions by paying part of their employees' salaries as "envelope wages" - unofficial, off-the-book wage payments. Moreover, if the economy is characterized by a legally established minimum wage regime, the minimum wage imposes a lower bound on the reported wages for those firms that don't want to take the risk of entering the shadow economy completely.

The practice of paying envelope wages is particularly widespread in the countries of Eastern Europe. For instance, according to a study by Williams (2009) conducted for
EU member states, the countries characterized by the highest degree of earnings underreporting are Romania (23 percent), Latvia (17 percent) and Bulgaria (14 percent). In Ukraine, according to Williams (2007), 31 percent of workers were found to be paid envelope wages.

Firms engaged in wage underreporting are most likely to choose values close to the minimum wage level to report to the tax authorities. Consequently, the large share of workers clustering around the minimum wage level in the country's wage distribution may be a sign of underreporting activity. For instance, Tonin (2011) showed that there is a high degree of correlation between the share of workers receiving about 105 percent of the legal minimum wage in 2002, and the size of the informal economy in 2001, as calculated by Schneider (2005). Figure 1 presents the relationship between share of workers receiving the minimum wage in 2014 according to Eurostat, and share of workers who receive envelope wages, as estimated by Williams (2013). As one can see, there is a clear positive correlation between the size of the spike in the minimum wage level and the share of workers receiving envelope wages.

As the minimum wage imposes a lower bound on the amount of reported wages, and many firms are believed to report wages near this lower bound, the increase in the legal 
minimum wage level will lead to higher tax contributions from firms engaged in wage underreporting. According to the World Bank Ukraine Economic Update of April 10, 2018, the year of 2017 was characterized by a 20 percent increase in real tax revenues, driven by the hike in wages. That is, for Ukraine the minimum wage increase seemed to be an effective instrument for boosting tax revenues.

Economic theory predicts that a minimum wage increase will affect the economy through several channels. First, a minimum wage increase stimulates demand for goods from minimum wage workers, and increases their savings. Second, the costs of the firm increase, which induces the firm to adjust its output, prices and the combination of its inputs. Third, all other agents in the economy are affected through the change in demand for the inputs in their possession, and through the change in prices of final goods.

Wage underreporting complicates the mechanism by which minimum wage increases affect the economy. First, the wage of true minimum wage workers increases, which stimulates their demand for final goods and allows them to save more. Second, the disposable income of workers engaged in underreporting decreases, since now they have to reveal a larger part of their true income to the tax authorities, and consequently their consumption and savings fall. Third, the costs of firms increase both because of the higher wages of true minimum wage earners and the higher tax contributions for labor for which salaries are underreported. As a result, the firm adjusts its level of output, prices of output and the combination of inputs - including the number of workers receiving envelope wages. Fourth, the tax revenues of the government go up, which potentially leads to higher government spending. And finally, all other participants in the economy are affected through the new final prices for goods, and change in demand for inputs.

For the purposes of present study I built a New-Keynesian DSGE model on a basic NK DSGE framework with capital accumulation (Gali, 2008; Yun, 1996), and price stickiness modeled as price adjustment costs a la Rotemberg (1982). The basic NK DSGE model is extended in three directions.

First, basic labor heterogeneity is added: low-skilled labor and high-skilled labor. Low-skilled labor is assumed to be subject to the minimum wage. Since the minimum wage is a policy instrument, it is modeled as a stochastic exogenous process.

The second extension of the basic model allows for two types of households: Ricardian households and Non-Ricardian households. Ricardian households have access to the capital and financial markets, and as a result can engage in intertemporal consumption smoothing. Non-Ricardian households are cut off from financial markets, and consequently each period consume all of their disposable income. The inclusion of the second type of household was motivated by empirical evidence that an increase in current income leads to a significant increase in consumption (Mankiw, 2000). Since nominal minimum wage shocks combined with sticky prices lead to changes in the real disposable income of agents, the inclusion of this second type of household aims to bring more plausible dynamics to aggregate variables.

Three types of taxes are explicitly modeled: the labor income tax imposed on households, the social security tax

\section{Figure 1. Envelop Wages Percentage and the Spike in the Minimum Wage Level in the Wage Distribution of a Country}

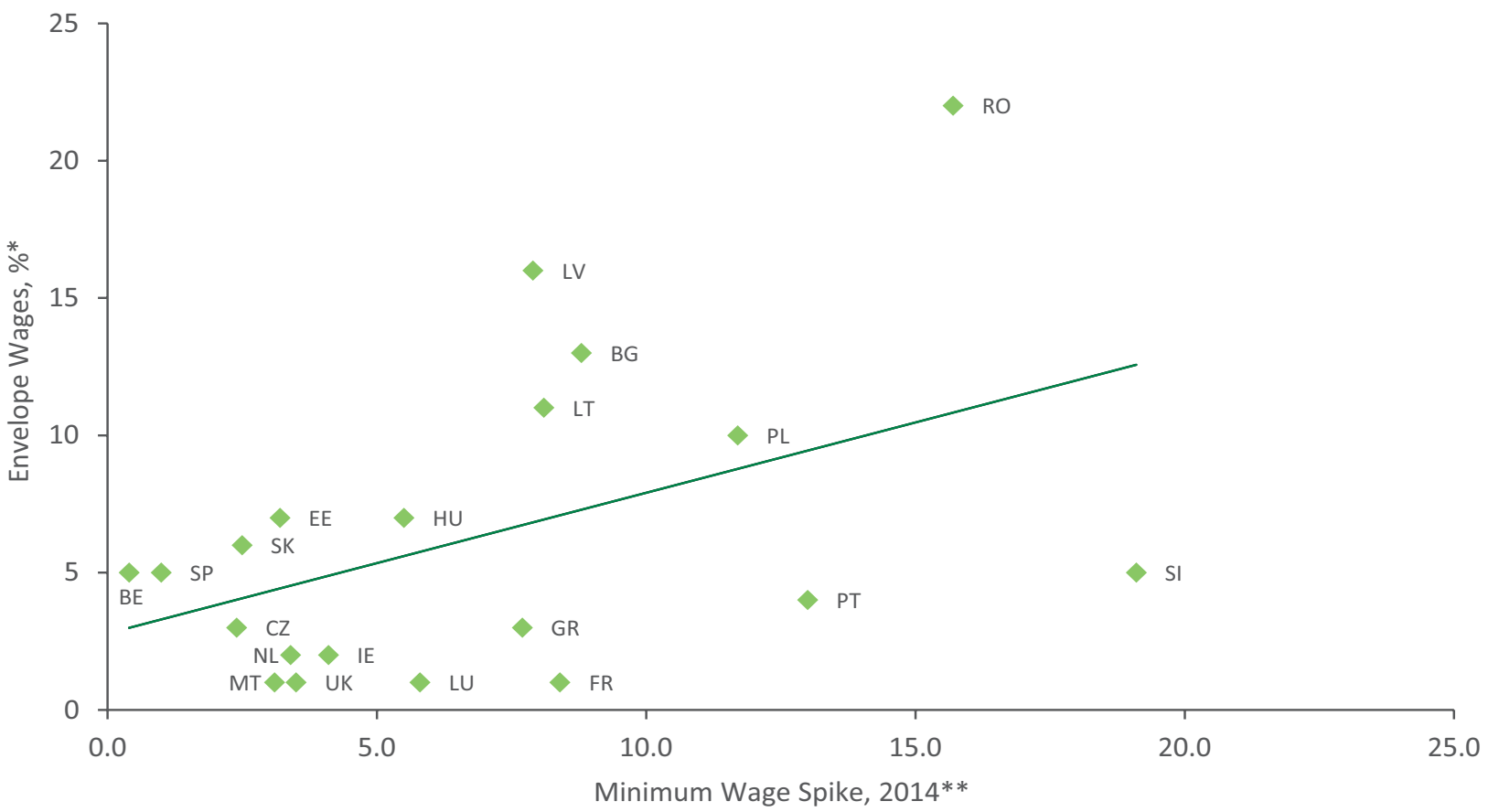

Source:

* Williams (2013)

**ec.europa.eu 
imposed on firms, and the tax on final output. Labor income tax and social security tax are modeled because they are explicitly tied to the optimization problems of households and firms respectively. The tax on final output is included because the largest share of tax revenues in economies like that of Ukraine comes from the VAT tax.

Third, incentives for underreporting are included in the model. In the spirit of Orsi et al. (2014), I assume that high-skilled labor can be supplied both formally - that is with full reporting of wages to the tax authorities, and informally - that is with reporting of only the minimum wage to the tax authorities. Agents derive additional disutility from informal employment, but receive higher wages. Firms, on the other hand, hire both formal and informal labor and face the probability of being audited. In the case of its being audited, the firm is forced to pay a fine greater than the underpaid taxes.

This research aims to investigate the aggregate effects of a minimum wage increase in an economy in which there is the underreporting of wages, and, in particular, to answer this question: What role does the presence and degree of underreporting play in forming the macroeconomic response to an increase in the minimum wage?

The extended model allows us to examine how the presence and size of underreporting alters the aggregate effects of a minimum wage shock, as well as conventional structural shocks - productivity shocks and monetary shocks.

This paper is organized as follows. In section 2 a review of the literature is presented. Section 3 describes the mode setup. Section 4 provides details on the calibration and estimation of model parameters. In section 5, results are discussed. Finally, section 6 provides conclusions.

\section{LITERATURE REVIEW}

The vast majority of the literature on minimum wages focuses on its employment effect, as there is conflicting evidence on the direction of this effect - see, for instance, Card and Krueger (1995). In particular, when estimating the effect of a minimum wage increase on employment in the U.S. fast-food industry, Card and Krueger obtained the striking result that a minimum wage increase has a positive effect on employment. However, Dickens et al. (1999) found there was a neutral effect from a minimum wage increase on employment - a result that again was not consistent with the predictions of the standard theory of the competitive labor market. Dickens et al. (1999) built a theoretical mode of a labor market featuring monopsony power by firms, and showed that the absence of adverse effects of a minimum wage increase on employment might be due to the presence of monopsonistic competition on the labor market. Also, Dube et al. (2011) demonstrated a dynamic monopsony model in which a higher minimum wage attracts more workers to the firm, suggesting that a higher minimum wage may reduce labor flows rather than employment levels. However, Aaronson and French (2006) in their study of the fast-food industry in the United States showed that monopsony power is not an important factor contributing to the low response of employment to a minimum wage increase.

The number of studies addressing the effect of the minimum wage on prices is very limited. A comprehensive survey of such studies was done by Lemos (2008). Most of the empirical research seems to conclude that a minimum wage increase has a positive but very moderate effect. For instance, Aaronson (2001), using various sources of restaurant prices, concluded that prices do indeed rise in response to a minimum wage increase - the higher costs are passed onto consumers. According to Lemos (2008), in the United States, the average (across studies) increase in prices is about 0.4 percent from a 10 percent minimum wage increase. Lemos (2005) also studied the economy-wide price effects of a minimum wage increase, this time in Brazil, and found that a 10 percent increase in minimum wages was associated with a 3.5 percent increase in prices.

In addition, Lemos (2004) estimated the effects of a minimum wage increase on both the formal and informal sectors in Brazil. She found that the wage effects of the minimum wage increase were strong, as such an increase compresses the wage distribution, while there are no effects on employment. Generally, the size of the effect on prices of the minimum wage increase depends on the share of workers receiving the minimum wage. But in an environment characterized by the underreporting of earnings, the minimum wage imposes a lower bound on the reported (and therefore taxable) wages of firms and households who don't want to bear the risk of becoming completely informal. As a result, in such economies tax revenues also depend on the minimum wage policy, as well the income of workers and the costs of firms engaged in underreporting (World Bank, 2005).

The phenomenon of underreporting of earnings is particularly relevant to developing countries. For instance in 2007 , the percentage of official workers receiving part of their wage as envelope wages was particularly high in the countries of Central and Eastern Europe: 23 percent for Romania, 17 percent for Latvia, and 14 percent for Bulgaria (Williams, 2009). In Ukraine in 2005 and 2006 about 31 percent of all workers were paid envelope wages (Williams, 2007).

As the minimum wage imposes the lower bound on the amount of declared earnings, a spike at the minimum wage level in the observed wage distribution may be an indicator of the degree of underreporting in the economy (Tonin, 2011) where workers and firms choose to report the minimum wage instead of the true wage. Tonin (2011) investigated data from Hungarian households, and found that the consumption of those who should have been positively affected by the minimum wage increase had in fact decreased, which is a strong sign of underreporting. Furthermore, Tonin (2011) developed a theoretical model of a labor market with wage underreporting and imperfect detection, where workers and firms agree to underreport part of the wage. He showed that the introduction of a minimum wage in the model creates a spike at the minimum wage level in the wage distribution similar to that observed in the data. Moreover, in the model of Tonin (2011), the presence of underreporting is associated with a lower impact of minimum wage shocks on employment.

Feldina and Polanec (2012) investigated the impact of a minimum wage increase on firms of different sizes, as it is assumed that smaller firms are more likely to participate in informal activities. They found that for smaller firms, the employment effects of a minimum wage increase are lower than for larger firms.

Since in economies characterized by earnings underreporting minimum wage policy affects not only those working under the minimum wage but also those who are 
engaged in underreporting and, consequently, tax revenues, the presence of underreporting may be an important mechanism modulating the macroeconomic effect of a minimum wage increase.

There is a limited amount of literature addressing the effects of minimum wage adjustments on the business cycle in the scope of a theoretical dynamic general equilibrium framework. Heberer (2010), however, includes the minimum wage in a simple DSGE framework, and finds that - as is predicted by theory - the economy is generally adversely affected when a minimum wage is introduced. Porter and Vitek (2008) estimated the impact of introducing the minimum wage on business cycle volatility in the Hong Kong SAR. Their conclusion is that introducing the minimum wage may increase macroeconomic volatility, as labor markets under the minimum wage are less flexible.

Glover (2018) investigates the aggregate effects of increasing the minimum wage when interest rates in the economy hit the zero lower bound, with the help of a New-Keynesian DSGE framework. His conclusion is that in normal times (away from the zero lower bound) under a monetary policy conducted according to the standard Taylor Rule, the effect of a minimum wage increase is contractionary.

A nominal minimum wage also results in a special type of downward nominal wage rigidity. The implications of the downward nominal wage rigidities (DWNR) for the economy have to this point been addressed in several studies, including Benigno and Ricci (2011), and Schmitt-Grohe and Uribe (2013). One particular feature of the nominal minimum wage is that, unlike the general type of downward nominal wage rigidity the nominal wage is a policy instrument. For instance, in highinflationary environments the general type of DWNR loses its power (Schmitt-Grohe and Uribe, 2013), while the nominal minimum wage is repeatedly increased by the government in order to keep up with inflation, and consequently a mechanism preventing the economy from achieving full employment is maintained. Under high inflation, in periods of government inactivity with respect to the nominal minimum wage, the distorting power of the nominal minimum wage declines (as the real minimum wage decreases), but when a government pursues an active policy of increasing the nominal minimum wage, the situation is reversed.

The goal of increasing the minimum wage is to increase the disposable income of minimum wage workers. Aaronson et al. (2012) found that an increase in income due to a minimum wage hike is followed by an even larger increase in spending. There is extensive empirical evidence that increasing current income leads to a significant increase in consumption - see, for instance, Mankiw (2000) and Gali et al. (2007). In particular, as is stated in Mankiw (2000), the presence of very low-wealth households, in which making savings is not a typical activity, could explain the strong response of consumption to an increase in current income. Gali et al. (2007) built a New-Keynesian model in which one portion of the households behaves in the standard Ricardian fashion - that is they can save and borrow for future periods - while the other portion has no access to capital markets, and consequently consume their entire income each period (so called non-Ricardian households). According to Gali et al. (2007), an increase in government spending leads to an increase in aggregate demand, which in turn leads to an increase in real wages, since firms, facing sticky prices, adjust their output. The increase in labor income stimulates consumption in non-Ricardian households. The presence of borrowing-constrained households also has important implications for monetary policy, as the presence of such households undermines the effectiveness of interest rate monetary policy - see Kaplan et al. (2018).

While to my knowledge there are no theoretical dynamic general equilibrium models specifically modeling wage underreporting, there is extensive literature on modeling informality and the shadow economy. Busato and Charini (2002) developed a two-sector dynamic stochastic general equilibrium model to study the influence of the shadow economy on the business cycle. They found that informal economic activity presents income smoothing opportunities for households. Castillo and Montoro (2010) built a New-Keynesian model with informal labor and search frictions, and showed that the presence of an informal economy serves a "buffer" that diminishes the effect of demand shocks. Orsi et al. (2014) studied the underground economy in a modified two-sector stochastic growth model estimated for Italy, and found that the size of the shadow economy is very sensitive to the tax rate. Cesaroni (2014) built a New-Keynesian model with a formal and informal sector and showed that the presence of downward nominal wage rigidities in the formal sector strongly affects the allocation of labor between the two sectors.

\section{MODEL}

The model is built on the basis of a textbook monetary DSGE model of a closed economy with capital accumulation (see Gali, 2008; Yun, 1996). The time of the model is discrete and the time horizon is infinite. The model consists of two types of households: Ricardian and non-Ricardian, perfectly competitive intermediate, and monopolistically competitive final goods producers, a monetary authority following the interest rate rule, and a fiscal authority collecting taxes from households and firms.

\subsection{Households}

There are two types of households. Ricardian households, which have access to financial markets, and consequently can smooth their consumption intertemporarily, and NonRicaridian households, which are cut off from the financial markets and consume all of their disposable income every period. The share of non-Ricardian households is $\gamma$. Both types of households supply low and high-skilled labor. The high-skilled labor can be supplied formally or informally. By informal labor I mean high-skilled labor for which only the minimum wage is reported to the tax authorities.

\subsubsection{Ricardian Households}

Ricardian households can invest in capital and trade one-period nominal interest bearing private bonds Such households also own private firms and receive their profits. They consume, supply low-skilled labor and high-skilled labor, and pay tax from labor income.

These households maximize expected lifetime utility:

$$
\begin{aligned}
E_{0}\left(\sum _ { t = 0 } ^ { \infty } \beta ^ { t } \left(\frac{c_{r, t}^{1-\sigma}}{1-\sigma}-\right.\right. & \Gamma^{u} \frac{\left(n_{r, t}^{u}\right)^{1+\varphi^{u}}}{1+\varphi^{u}}-\Gamma^{h} \frac{\left(n_{r, t}^{f}+n_{r, t}^{i}\right)^{1+\varphi}}{1+\varphi}- \\
& \left.\left.-\Gamma^{i} \frac{\left(n_{r, t}^{i}\right)^{1+\varphi^{i}}}{1+\varphi^{i}}\right)\right)
\end{aligned}
$$


Their inter-temporal budget constraint is:

$$
\begin{gathered}
P_{t} c_{r, t}+P_{t}\left(k_{r, t}-(1-\delta) k_{r, t-1}\right)+R_{t-1} b_{t-1}+ \\
+P_{t} \xi_{k, t}\left(k_{r, t}, k_{r, t-1}\right)=\left(1-\tau_{h}\right)\left(W_{t}^{u} n_{r, t}^{u}+\right. \\
\left.+W_{t}^{f} n_{r, t}^{f}\right)+W_{t}^{i} n_{r, t}^{i}-\tau_{h} W_{t}^{\min } n_{r, t}^{i}+ \\
\quad+r_{t}^{k} k_{r, t-1}+b_{t}+d_{r, t}
\end{gathered}
$$

where $c_{r, t}-$ consumption of the household; $k_{r, t}-$ capital savings; $W_{t}^{u}$-wage paid for low-skilled labor; $W_{t}^{f}$-wage paid for high-skilled formal labor; $W_{t}^{i}$ - wage paid for high-skilled informal labor; $n_{r, t}^{u} n_{r, t}^{f} n_{r, t}^{i}-$ household labor supplied as low-skilled and high-skilled, formal or informal, respectively; $r_{t}^{k}$-real return on capital; $b_{t}$ - bond holdings; $d_{r, t}$ - dividends from owning firms; $\Gamma^{u}, \Gamma^{h}, \Gamma^{i}-$ disutility parameters for low-skilled labor, total high-skilled labor and informal labor; $\varphi^{u}, \varphi, \varphi^{i}$ are inverse Frisch labor supply elasticity parameters for low-skilled, high-skilled and informal labor.

Since private bonds are zero in net supply and all households holding bonds are identical, bond holdings of the household are 0 in equilibrium.

Capital adjustment costs are given by: ${ }^{1}$

$$
\xi_{k, t}\left(k_{t}, k_{t-1}\right)=\psi \frac{k_{t-1}}{2 \delta}\left(\frac{k_{t}-(1-\delta) k_{t-1}}{k_{t-1}}-\delta\right)^{2},
$$

where $\psi$ is the parameter regulating the costs of capital adjustment.

\subsubsection{Non-Ricardian Households}

Non-Ricardian households have no access to capital and financial markets. The reason for including non-Ricardian households is to obtain a more plausible response to the minimum wage increase, as when current real income goes up, the large increase in consumption demand is mainly generated by households behaving in a non-Ricaridan fashion. Each period, non-Ricaridan households consume all of their income. Otherwise, they are identical to the Ricardian households. Non-Ricardian households maximize current period utility:

$$
\begin{gathered}
\frac{c_{n, t}^{1-\sigma}}{1-\sigma}-\Gamma^{u} \frac{\left(n_{n, t}^{u}\right)^{1+\varphi^{u}}}{1+\varphi^{u}}- \\
-\Gamma^{l} \frac{\left(n_{n, t}^{f}+n_{n, t}^{i}\right)^{1+\varphi}}{1+\varphi}-\Gamma^{i} \frac{\left(n_{n, t}^{i}\right)^{1+\varphi^{i}}}{1+\varphi^{i}} .
\end{gathered}
$$

Their budget constraint each period is:

$$
\begin{aligned}
P_{t} c_{n, t}= & \left(1-\tau_{h}\right)\left(W_{t}^{u} n_{n, t}^{u}+W_{t}^{f} n_{n, t}^{f}\right)+ \\
& +W_{t}^{i} n_{n, t}^{i}-\tau_{h} W_{t}^{\min } n_{n, t}^{i} .
\end{aligned}
$$

\subsection{Production}

Homogeneous intermediate goods are produced using labor and capital and are then sold to final goods producers (retailers). Final goods producers are involved in monopolistic competition and are price setters.

\subsubsection{Intermediate Goods Producers}

Intermediate goods producers employ inputs on the respective perfectly competitive markets and produce homogeneous goods. Their production function is:

$$
Y_{I, t}=A_{I, t}\left(K_{t}\right)^{\alpha}\left(L_{t}\right)^{1-\alpha},
$$

where $Y_{l}$ - intermediate output; $K_{t}$ - capital input; $L_{t}$ - labor input; $A_{l, t}-$ stochastic total factor productivity or TPF).

The TFP process is given by:

$$
\begin{gathered}
\ln \left(A_{t}\right)-\ln (\bar{A})=\rho_{A}\left(\ln \left(A_{t-1}\right)-\right. \\
-\ln (\bar{A}))+\epsilon_{A}, \epsilon_{A} \sim N\left(0, \sigma_{A}\right) .
\end{gathered}
$$

Labor input is constructed from high-skilled labor and low-skilled labor with the help of a constant elasticity of substitution aggregator:

$$
L_{t}=\left(b\left(L_{t}^{u}\right)^{\frac{\epsilon_{L}-1}{\epsilon_{L}}}+(1-b)\left(L_{t}^{f}+L_{t}^{i}\right)^{\frac{\epsilon_{L}-1}{\epsilon_{L}}}\right)^{\frac{\epsilon_{L}}{\epsilon_{L}-1}} .
$$

Firms choose inputs to maximize profits expected for the current period (at the beginning of the period):

$$
E\left\{P_{I, t} Y_{I, t}-C\left(Y_{I, t}\right)\right\}
$$

Uncertainty arises because, following Orsi et al. (2014), it is assumed that firms face tax on labor and are involved in tax evasion. Each period they face the probability $p$ of being audited, in which case they pay a surcharge s over the minimum wage for each informal worker.

In contrast to Orsi et al. (2014), in this paper firms do not hide any output, but instead underreport wages for part of their hired labor. That is, for high-skilled labor, an informal firm reports that this labor is paid the minimum wage, when in reality this wage is higher.

The expected costs of the firm are given by:

$$
\begin{gathered}
E\left\{C\left(Y_{I, t}\right)\right\}=r_{t}^{k} K_{t}+W_{t}^{\min } L_{t}^{u}\left(1+\tau_{s}\right)+ \\
W_{t}^{f} L_{t}^{f}\left(1+\tau_{s}\right)+W_{t}^{i} L_{t}^{i}+W_{t}^{m i n} L_{t}^{i}\left(\tau_{s}+p s\right),
\end{gathered}
$$

where $\tau_{s}$ is a social security tax.

\subsubsection{Final Goods Production}

There is a continuum of monopolistically competitive final goods producers of measure 1 . The $i$-th producer buys intermediate goods and produces differentiated final good. Their production function is:

$$
Y_{F, t}(i)=Y_{I, t}(i)
$$

Each producer faces a downward-sloping demand curve for its product.

\footnotetext{
${ }^{1}$ Adjustment costs are needed in New-Keynesian models in order to eliminate an absurd increase in the capital to output ratio in response to nominal interest rate changes. Authors often use investment adjustment costs in NK models as opposed to capital adjustment costs, since this brings a hump-shaped response of investment to a monetary shock, see Christiano, Eichenbaum and Evans (2005). Here capital adjustment costs are used for simplicity - this form of adjustment costs is found, for example, in Gornemann et al. (2012) and lacovello (2005).
} 
Final goods producers face quadratic costs of price adjustment, as in Rotemberg (1982), and maximizes the stream of real profits:

$$
\begin{aligned}
E_{0} & \sum_{t=0}^{\infty} Q_{0, t}\left(\left(1-\tau_{c}\right) P_{t}(i) Y_{F, t}(i)-\right. \\
& \left.-P_{I, t} Y_{I, t}(i)-P_{t} \xi_{p, t} Y_{F, t}(i)\right)
\end{aligned}
$$

where $\tau_{c}$ - VAT tax.

Since households own the firms, the discount factor of future nominal profits is (see Gali textbook):

$$
Q_{t, t+1}=E_{t}\left(\beta \frac{c_{r, t+1}^{-\sigma}}{c_{r, t}^{-\sigma}} \frac{1}{\pi_{t+1}}\right) .
$$

Price adjustment costs are given by:

$$
\xi_{p, t}=\frac{\Phi}{2}\left(\frac{P_{t}(i)}{P_{t-1}(i)}-\pi_{s s}\right)^{2} .
$$

The final goods index, aggregated via the CES aggregator (as in Gali textbook):

$$
Y_{F, t}=\left(\int_{0}^{1}\left(Y_{F, t}(i)\right)^{1-\frac{1}{\epsilon}} d i\right)^{\frac{\epsilon}{\epsilon-1}} .
$$

From the final goods index the demand for the $i$-th firm's final goods is derived to be:

$$
Y_{F, t}(i)=Y_{F, t}\left(\frac{P_{t}(i)}{P_{t}}\right)^{-\epsilon}
$$

The final goods index is used for consumption, capital investment and bearing price adjustment costs.

Dividends from the $i$-th firm are:

$$
\begin{aligned}
D_{t}(i) & =\left(1-\tau_{c}\right) P_{t}(i) Y_{F, t}(i)-P_{t}^{I} Y_{I, t}(i)- \\
& -P_{t} \xi_{p, t}\left(P_{t-1}(i), P_{t}(i)\right) Y_{F, t}(i)
\end{aligned}
$$

Dividends of all firms are divided between the firms' owners:

$$
D_{t}=\int_{0}^{1} D_{t}(i) d i
$$

\subsection{Central Bank}

Monetary policy is conducted via a Taylor (1999) -type interest rate rule:

$$
\begin{gathered}
\ln \left(R_{t}\right)-\ln \left(R_{S S}\right)=\left(1-\rho_{R}\right)\left(\rho _ { \pi } \left(\ln \left(\pi_{t}\right)-\right.\right. \\
\left.\left.-\ln \left(\pi_{S S}\right)\right)+\rho_{Y}\left(\ln \left(Y_{F, t}\right)-\ln \left(Y_{F, S S}\right)\right)\right)+ \\
+\rho_{R}\left(\ln \left(R_{t-1}\right)-\ln \left(R_{S S}\right)\right)+\epsilon_{R} .
\end{gathered}
$$

Since the monetary transmission mechanism is not modeled explicitly, it is assumed that the interest rate set by the Central Bank is passed perfectly to the interest paid on private bonds, so that both are equal.

\subsection{Minimum Wage}

Since low-skilled labor is demand-constrained under the minimum wage, it is assumed that both non-Ricardian and Ricardian households face the same demand for low-skilled labor, and consequently both supply the sam amount of low-skilled labor:

$$
n_{n, t}^{u}=n_{r, t}^{u}
$$

The wage paid to low-skilled labor is specified by the government:

$$
W_{t}^{u}=W_{t}^{\min } .
$$

It is assumed that households always want to supply more low-skilled labor than is demanded at the minimum wage, so the quantity of low-skilled labor supplied is fully determined by demand.

The real minimum wage process is:

$$
\begin{gathered}
\ln \left(W_{t}^{\min }\right)-\ln \left(W_{s s}^{\min }\right)=\rho_{W}\left(\ln \left(W_{t-1}^{\min }\right)-\right. \\
\left.-\ln \left(W_{s s}^{\min }\right)\right)+\rho_{\pi W}\left(\ln \left(\pi_{t}\right)-\ln \left(\pi_{s s}\right)\right)+\epsilon_{W}
\end{gathered}
$$

where $\varepsilon_{W}$ is an exogenous stochastic process with zero mean.

If the indexation of the nominal minimum wage was perfect, the real minimum wage wouldn't depend on inflation. But since the government doesn't perfectly index the nominal wage each period, there is a negative relationship between the real wage and inflation $\left(\rho_{\pi W}<0\right)$.

\subsection{Fiscal Authority}

It is assumed that each period government runs balanced budget:

$$
\begin{gathered}
G_{t}=\left(\tau_{s}+\tau_{h}\right)\left(W_{t}^{u} L_{t}^{u}+W_{t}^{f} L_{t}^{f}+W_{t}^{\min } L_{t}^{i}\right)+ \\
+\tau_{c} P_{t} Y_{F, t}+s p W_{t}^{\min } L_{t}^{i},
\end{gathered}
$$

where $G_{t}-$ government spending

\subsection{Market Clearing}

The capital market clears:

$$
(1-\gamma) k_{r, t-1}=K_{t}
$$

The low-skilled labor market clears:

$$
n_{n, t}^{u}=n_{r, t}^{u}=L_{t}^{u} .
$$

The high-skilled labor market clears:

$$
\gamma n_{n, t}^{f}+(1-\gamma) n_{r, t}^{f}=L_{t}^{f} .
$$

The informal labor market clears:

$$
\gamma n_{n, t}^{i}+(1-\gamma) n_{r, t}^{i}=L_{t}^{i} .
$$

The intermediate goods market clears:

$$
Y_{I, t}=Y_{F, t}
$$


The final goods market clears:

$$
\begin{gathered}
Y_{F, t}=\gamma c_{n, t}+(1-\gamma) c_{r, t}+ \\
+G_{t}+(1-\gamma)\left(k_{r, t}-(1-\delta) k_{r, t-1}+\right. \\
\left.+\xi_{k, t}\left(k_{t}, k_{t-1}\right)\right)+\int_{0}^{1} \xi_{p, t} Y_{F, t}(i) d i .
\end{gathered}
$$

Dividends are paid to firm owners:

$$
(1-\gamma) d_{r, t}=D_{t}
$$

See Appendix A1 for the non-linear model system of equations and Appendix A2 for the log-linearized model. Steady-state ratios are calculated in Appendix A3.

\section{CALIBRATION AND ESTIMATION}

The subset of parameters is calibrated according to Ukrainian data. Other parameters are calibrated from the literature or estimated using a Bayesian estimation method.

I set the relative risk aversion coefficient $\sigma$ equal to 1 , which corresponds to the logarithmic utility function. For the calibration of $\pi_{s s}, \beta, \varepsilon, \alpha$ and the minimum wage to average wage steady-state ratio $S H$ wag, I use quarterly data for Ukraine for the period Q1 2006 to Q4 2017 obtained from Ukrstat, except for the interest rate time series, which is obtained from the NBU open dataset. The final dataset consists of a deseasonalized time-series for nominal GDP, nominal capital investment, nominal profits, the minimum wage, the average wage, and the yearly nominal interest rate on 3-6 month deposits. Steady-state inflation $\pi_{s S}$ is calibrated to match average quarterly inflation. As the model has the steady-state relationship $\beta=\frac{\pi_{s s}}{R_{s s}}$, I calibrate $\beta$ to match the average of the inflation to interest rate ratio, where the annual interest rate is modified to bring a quarterly return. The elasticity of substitution between various consumer goods in the model is steadystate $\varepsilon=\frac{\left(1-\tau_{c}\right) Y_{s s}}{D_{s s}}$. Therefore, I calibrate $\varepsilon$ to match the average profits to output ratio multiplied by $1-\tau_{c}$. The capital income share $\alpha$ is calibrated according to the average investment to output ratio, since $\alpha=\frac{K_{S s}}{Y_{S S}} r_{k}^{s s}=\frac{I_{S S} r_{k}^{s S}}{Y_{S S} \delta}$, where $r_{k}^{s S}=\delta-1+\frac{1}{\beta}$. The minimum wage to average wage steady-state ratio SHwag is calibrated to match the average ratio in the data. The rate of depreciation of physical capital $\delta$ is set to the quarterly equivalent of the average over the sample available in the Penn World Table (1990-2014). The probability of being audited $p$ is set to the ratio of the number of firms that the Ukrainian fiscal authority plans to inspect in the year 2018 (according to the announcement on their website) to the total number of firms in Ukraine (available at Ukrstat), and adjusted for quarterly frequency. The fine or surcharge $s$ is calibrated according to Article 265 of the Ukrainian Labor Code, which prescribes the special fine in the case of underreporting being detected to be equal to 30 monthly minimum wages, and is also adjusted for quarterly frequency. Tax rates $\tau_{s}, \tau_{h}$ and $\tau_{c}$ are set to much Ukrainian social security tax, income tax and VAT tax rates. The share of labor reporting the minimum wage, SHmin, is calibrated, in accordance with Ukrstat's September 2017 data on the distribution of wages, to be equal to share of workers whose earnings are less than $\mathrm{UAH} 4,000$. As the minimum wage set in that period was $\mathrm{UAH} 3,200$, the reported minimum wage share in the model corresponds to the share of people who report less than 125 percent of the minimum wage. The share of underreporting of labor, SHinf, is calibrated according to the results of a poll conducted by the HeadHunter labor agency $^{2}$ in 2017. Minimum wage parameters $\rho_{\pi W}, \rho_{W}, \sigma_{\varepsilon W}$ are calibrated by regressing the real minimum wage on the respective variables. Monetary rule parameters and monetary shock standard deviations $\rho_{R}, \rho_{\pi}, \rho_{Y}$ and $\sigma_{\varepsilon R}$ are calibrated according to Smets and Wouters (2003). ${ }^{3}$ The share of non-Ricardian households, SHnon, is set to $0.35 .^{4}$ The elasticity of substitution between low and high skilled labor $\varepsilon_{L}$ is set to 2 , see (Behar, 2010). Calibration results are presented in Table B1 (Appendix B).

The remaining parameters are estimated using a Bayesian estimation method. Prior distributions for the productivity autocorrelation parameter $\rho_{A}$, the productivity shock standard deviation $\sigma_{A}$, the capital adjustment cost parameter $\psi$ are chosen as in lacovello (2015). The prior for $\rho_{A}$ is a beta distribution with a mean of 0.8 and a standard deviation of 0.1. The prior for $\sigma_{A}$ is inverse gamma distribution with a mean of 0.005 and a standard deviation of 0.025 . The prior for $\psi$ is a gamma distribution with a mean of 1 and a standard deviation of 0.5. Price adjustment costs parameter $\Phi$ prior is set to a gamma distribution with a mean of 20 and standard deviation of 10 as in Shintaniv (2016). The inverse Frich elasticity of labor supply $\varphi$ is set to have gamma distribution prior, with a mean of 1 and a standard deviation of 0.1, following Orsi et al. (2014). The inverse Frich elasticity of the informal labor supply $\varphi^{i}$ is set to follow a gamma distribution prior with a mean of 1 and a standard deviation of 0.5. The time series used for estimation are quarterly GDP, and capital investment and inflation taken for the period Q1 2006 to Q4 2017. The GDP and investment series are detrended via a Hodrick-Prescott filter with standard for the quarterly data $\lambda=1,600$. Priorsandestimation results can befound in Table B2 (Appendix B).

\section{DISCUSSION OF RESULTS}

In this chapter I conduct the following exercises. First, I look at and discuss the impulse responses to the minimum wage shock, depending on the degree of underreporting that takes place in the economy. Second, I investigate how the assumed share of non-Ricaridan households alters the impulse response of inflation to the minimum wage shock.

Figure C1.1. (in Appendix C1) shows the impulse responses of the key macroeconomic variables to a positive minimum wage shock of 1 standard deviation. Along with the calibrated version, I show impulse responses for alternative shares of underreporting of labor. As we can see in Figure C1.1. (in Appendix C1), a higher degree of underreporting leads to quantitatively lower (in absolute value) responses of inflation, output, and investment to the minimum wage shock. If the degree of underreporting is high, fewer households experience an actual increase in labor income, hence the demand increase is lower. On the other hand, firms' costs do not increase as much as they would have if the underreporting workers were actually minimum wage earners. Also, since the labor costs of firms don't rise as sharply as they would have under a low degree of underreporting, the drop in labor

\footnotetext{
${ }^{2}$ https://kiev.hh.ua/article/20673

${ }^{3}$ Since Ukraine adopted inflation targeting only recently, estimates of the interest rate rule obtained from Ukrainian data are unreliable.

${ }^{4}$ Marto (2013) notes that for European countries, the share of non-Ricadian households estimated in the literature is between 25 percent and 37 percent.

I address the importance of share of non-Ricardian households for the model's dynamics in the discussion of the results.
} 
hours is smaller under a higher degree of underreporting. Under a low degree of underreporting, the consumption of Non-Ricardian households initially rises due to the initial increase in real labor income.

Figure C1.2. (in Appendix C1) shows the relationship between the degree of underreporting and the impact response of inflation, output, and nominal interest rates to a minimum wage shock. We can see that under a higher degree of underreporting, the inflation increase and initial output deviation are not as severe. Moreover, under the assumption of a high share of non-Ricaridan households, the initial output response is positive, since the increase in nonRicardian consumption following a real minimum wage hike stimulates output in the short run.

Generally, a minimum wage increase affects the economy through four main channels: output demand, output supply, inputs demand, and inputs supply. ${ }^{5}$ In an economy characterized by underreporting, different groups of workers are affected in different ways by a minimum wage shock, and thus pull output demand in different directions. Moreover, since in an economy with wage underreporting a minimum wage increase leads to higher tax revenues, government spending also increases, which stimulates demand. Labor costs by firms are also affected differently when underreporting is present, since low-skilled workers become more expensive and the costs associated with underreporting also increase, which translates into a change in labor demand and into an increase in output prices.

Responses to other aggregate shocks are reported in Appendix C2. Notably, the degree of underreporting does not seem to have a strong effect on impulse responses to conventional aggregate shocks.

Now I look at how main result is altered if we assume different shares of non-Ricardian households. Impulse responses to a minimum wage shock for different shares of non-Ricaridan households are presented in Figure C1.3 (in Appendix C1). As we can see, a higher share of nonRicardian households brings higher inflation in response to a minimum wage increase. This is because nonRicaridan households are very responsive to changes in current income. And since under sticky prices a minimum wage increase affects current real income, demand for consumption is also affected more strongly when the share of non-Ricardian households is high.
Figure C1.4. (in Appendix C1) shows initial responses of inflation, output and nominal interest rates to a minimum wage shock. For higher assumed shares of non-Ricardian households, the initial responses are larger in magnitude. Generally, an economy populated with a larger share of nonRicardian households is more responsive to shocks affecting the current real income of agents.

The impulse responses to other shocks for different shares of non-Ricaridan households are given in Appendix $\mathrm{C} 2{ }^{6}$

\section{CONCLUSIONS}

Underreporting of wage earnings is a relevant issue in economies that have a minimum wage regime and the imperfect detection of tax evasion. The government's motivation for increasing the minimum wage in such economies often boils down to raising more tax revenues. On the other hand, there are general concerns associated with increasing the minimum wage, such as higher inflation, lower output, and a higher level of unemployment. In this research, I built a DSGE model featuring underreporting of earnings to answer the following question: How does underreporting affect the macroeconomic response to a minimum wage increase? The model predicts that a higher degree of underreporting results in a smaller increase of inflation and a smaller decrease in output, investment, and hours worked compared to an economy with a relatively low underreporting level. This is strong evidence that the presence of underreporting means that an economy is less affected by minimum wage shocks.

Qualitatively, the dynamics predicted by the model are in line with the general view on the effects of a minimum wage increase: in response to a minimum wage shock, inflation goes up, while output, investment and employment go down. The aggregate responses to conventional shocks do not depend on the degree of underreporting.

The final result depends rather on the share of nonRicardian households: the higher the share of non-Ricardian households, the higher is the volatility of inflation and output in response to a minimum wage shock.

Overall, in an economy with a high degree of wage underreporting, the negative effect of a minimum wage increase is smaller compared to an economy with a lower degree of underreporting.

\section{REFERENCES}

-Aaronson D. (2001). Price Pass-Through and the Minimum Wage. Review of Economics and Statistics, Vol. 83, No. 1, pp. 158-169. https://doi.org/10.1162/003465301750160126

- Aaronson D., Agarwal S., French E. (2012). The Spending and Debt Response to Minimum Wage Hikes. American Economic Review, Vol. 102, No. 7, pp. 3111-3139. https://doi.org/10.1257/aer.102.7.3111

Aaronson D., French E. (2007). Product Market Evidence on the Employment Effects of the Minimum Wage. Journal of Labor Economics, Vol. 25, No. 1, pp. 167-200. https://doi.org/10.1086/508734
Behar A. (2010). The Elasticity of Substitution Between Skilled and Unskilled Labor in Developing Countries is About 2. International Monetary Fund. Selected Works. Available at: https://works.bepress.com/alberto_behar/16/

Benigno P., Ricci L. A. (2011). The Inflation-Output Trade-Off with Downward Wage Rigidities. American Economic Review, Vol. 101, No. 4, pp. 1436-1466. https://doi.org/10.1257/aer.101.4.1436

Busato F., Chiarini B., Di Maro V. (2005). Using Theory for Measurement: An Analysis of the Behaviour of the Underground Economy. Working Paper No. 2005-19, University of Aarhus.

\footnotetext{
${ }^{5}$ For a description of the mechanism through which a minimum wage increase affects inflation, see, for example, Lemos (2008).

${ }^{6}$ Although beyond the scope of this study, it is worth mentioning that responses to monetary shocks are amplified if there are higher shares of non-Ricardian households, while responses to TFP shocks are partially stabilized with a higher non-Ricardian share, which is in line with Marto (2014).
} 
- Card D., Krueger A. B. (1995). Myth and Measurement. The New Economics of the Minimum Wage - TwentiethAnniversary Edition. Princeton; NJ: Princeton University Press.

- Castillo P., Montoro C. (2010). Monetary Policy in the Presence of Informal Labour Markets. Working Papers No. 2010-009, Banco Central de Reserva del Perú.

- Dickens R., Machin S., Manning A. (1999). The Effects of Minimum Wages on Employment: Theory and Evidence from Britain. Journal of Labor Economics, Vol. 17, No. 1, pp. 1-22. https://doi.org/10.1086/209911

- Dube A., Lester T. W., Reich M. (2011). Do Frictions Matter in the Labor Market? Accessions, Separations and Minimum Wage Effects. Discussion Papers No. 5811, Institute for the Study of Labor (IZA).

- Feldina A., Polanec S. (2012). Underreporting and Minimum Wage. Discussion Papers No. 32412, Centre for Institutions and Economic Performance, KU Leuven.

- Gali J. (2008). Monetary Policy, Inflation and the Business Cycle: An Introduction to the New Keynesian Framework. Princeton University Press.

• Gali J., López-Salido J. D., Vallés J. (2007). Understanding the Effects of Government Spending on Consumption. Journal of the European Economic Association, Vol. 5 , No. 1, pp. 227-270. https://doi.org/10.1162/JEEA.2007.5.1.227

- Glover A. (2018). Aggregate Effects of Minimum Wage Regulation at the Zero Lower Bound. Journal of Monetary Economics. https://doi.org/10.1016/j.jmoneco.2018.11.001

- Heberer E.-M. (2010). The Effects of a Minimum Wage in a Dsge Model: an Extension of the Benassy Model. Panorama Económico, Escuela Superior de Economía, Instituto Politécnico Nacional, Vol. 5, No. 10, pp. 7-39. https://doi.org/10.29201/pe-ipn.v5i10.78

- lacoviello M. (2015). Financial Business Cycles. Review of Economic Dynamics. Vol. 18, No. 1, pp. 140-163. https://doi.org/10.1016/j.red.2014.09.003

- Kaplan G., Moll B., Violante G. L. (2018). Monetary Policy According to HANK. American Economic Review, Vol. 108, No. 3, pp. 697-743. https://doi.org/10.1257/aer.20160042

- Lemos S. (2004). The Effects of the Minimum Wage in the Formal and Informal Sectors in Brazil. Discussion Papers No. 1089, Institute for the Study of Labor (IZA).

- Lemos S. (2005). Minimum Wage Effects on Wages, Employment and Prices: Implications for Poverty Alleviation in Brazil. Discussion Papers in Economics, No. 05/15, University of Leicester.

- Lemos S. (2008). A Survey of the Effects of the Minimum Wage on Prices. Journal of Economic Surveys, Vol. 22, No. 1 , pp. 187-212. https://doi.org/10.1111/j.1467-6419.2007.00532.x

- Mankiw N. G. (2000). The Savers-Spenders Theory of Fiscal Policy. American Economic Review, Vol. 90, No. 2, pp.: 120-125. https://doi.org/10.3386/w7571
- Marto, R. (2014). Assessing the Impacts of Non-Ricardian Households in an Estimated New Keynesian DSGE Model. Swiss Journal of Economics and Statistics, Vol. 150, No. 4, pp. 353-398. http://dx.doi.org/10.1007/bf03399411.

- Orsi R., Raggi D., Turino F. (2014). Size, Trend, and Policy Implications of the Underground Economy. Review of Economic Dynamics, Vol. 17, No. 3, pp. 417-436. https://doi.org/10.1016/j.red.2013.11.001

- Porter N., Vitek F. (2008). The Impact of Introducing a Minimum Wage on Business Cycle Volatility: A Structural Analysis for Hong Kong SAR. Working Paper No. 08/285, International Monetary Fund.

- Rotemberg J. J. (1982). Sticky Prices in the United States. Journal of Political Economy, Vol. 90, No. 6, pp. 1187-1211. https://doi.org/10.1086/261117

Schmitt-Grohé S., Uribe M. (2013). Downward Nominal Wage Rigidity and the Case for Temporary Inflation in the Eurozone. Journal of Economic Perspectives, Vol. 27, No. 3, pp. 193-212. https://doi.org/10.1257/jep.27.3.193

- Schneider F. (2005). Shadow Economies Around the World: What do we Really Know? European Journal of Political Economy, Vol. 21, No. 3, pp. 598-642. https://doi.org/10.1016/j.ejpoleco.2004.10.002

- Smets F., Wouters R. (2003). An Estimated Dynamic Stochastic General Equilibrium Model of the Euro Area. Journal of the European Economic Association, Vol. 1, No. 5, pp. 1123-1175. https://doi.org/10.1162/154247603770383415

- Taylor J. B. (1999). A Historical Analysis of Monetary Policy Rules. Monetary Policy Rules. University of Chicago Press, pp. 319-348.

- Tonin M. (2011). Minimum Wage and Tax Evasion: Theory and Evidence. Journal of Public Economics, Vol. 95, No. 11, pp. 1635-1651. https://doi.org/10.1016/j.jpubeco.2011.04.005

- Williams C. C. (2007). Tackling Undeclared Work in Europe: Lessons from a Study of Ukraine. European Journal of Industrial Relations, Vol. 13, No. 2, pp. 219-236. https://doi.org/10.1177/0959680107078254

- Williams C. C. (2009). Evaluating the Extent and Nature of "Envelope Wages" in the European Union: A Geographical Analysis. European Spatial Research and Policy, Vol. 16, No. 1, pp. 115-129. https://doi.org/10.2478/v10105-009-0007-3

- Williams C. C., Padmore J. (2013). "Envelope Wages" in the European Union. International Labour Review, Vol. 152, No. 3-4, pp. 411-430. https://doi.org/10.1111/j.1564913X.2013.00186.x

- World Bank (2005). Enhancing Job Opportunities: Eastern Europe and the Former Soviet Union. (Washington; World Bank.)

Yun T. (1996). Nominal Price Rigidity, Money Supply Endogeneity, and Business Cycles. Journal of Monetary Economics, Vol. 37, No. 2-3, pp. 345-370. https://doi.org/10.1016/S0304-3932(96)90040-9 


\section{APPENDIX A1. NON-LINEAR MODEL}

\section{Ricardian Households}

Budget constraint:

$$
\begin{gathered}
c_{r, t}+k_{r, t}-(1-\delta) k_{r, t-1}+\psi \frac{k_{t-1}}{2 \delta}\left(\frac{k_{t}-(1-\delta) k_{t-1}}{k_{t-1}}-\delta\right)^{2}= \\
=\left(1-\tau_{h}\right)\left(W_{t}^{u} n_{r, t}^{u}+W_{t}^{f} n_{r, t}^{f}\right)+W_{t}^{i} n_{r, t}^{i}-\tau_{h} W_{t}^{\min } n_{r, t}^{i}+r_{t}^{k} k_{r, t-1}+D_{r, t} .
\end{gathered}
$$

First order conditions:

$$
\begin{gathered}
c_{r, t}^{-\sigma}-\lambda_{r, t}=0, \\
-\Gamma^{h}\left(n_{r, t}^{f}+n_{r, t}^{i}\right)^{\varphi}+\lambda_{r, t}\left(1-\tau^{h}\right) W_{t}^{f}=0, \\
\Gamma^{i}\left(n_{r, t}^{i}\right)^{\varphi^{i}}=\lambda_{r, t}\left(W_{t}^{i}-\tau^{h} W_{t}^{m i n}-\left(1-\tau^{h}\right) W_{t}^{f}\right), \\
\lambda_{r, t}-\beta \lambda_{r, t+1} R_{t} / \pi_{t+1}=0, \\
-\lambda_{r, t}\left(1+\frac{\psi}{\delta}\left(\frac{k_{r, t}}{k_{r, t-1}}-1\right)\right)+\beta \lambda_{r, t+1}\left(1-\delta+r_{t+1}^{k}+\frac{\psi}{2 \delta}\left(\left(\frac{k_{r, t+1}}{k_{r, t}}\right)^{2}-1\right)\right)=0 .
\end{gathered}
$$

\section{Non-Ricardian Households}

Budget constraint:

$$
c_{n, t}=\left(1-\tau_{h}\right)\left(W_{t}^{u} n_{n, t}^{u}+W_{t}^{f} n_{n, t}^{f}\right)
$$

First order conditions:

$$
\begin{gathered}
c_{n, t}^{-\sigma}-\lambda_{r n, t}=0, \\
-\Gamma^{h}\left(n_{n, t}^{f}+n_{n, t}^{i}\right)^{\varphi}+\lambda_{n, t}\left(1-\tau^{h}\right) W_{t}^{f}=0, \\
\Gamma^{i}\left(n_{n, t}^{i}\right)^{\varphi^{i}}=\lambda_{n, t}\left(W_{t}^{i}-\tau^{h} W_{t}^{\min }-\left(1-\tau^{h}\right) W_{t}^{f}\right) .
\end{gathered}
$$

\section{Intermediate Gods Producers}

Technology is:

$$
Y_{I, t}=A_{I, t}\left(K_{t}\right)^{\alpha}\left(L_{t}\right)^{1-\alpha}
$$

Labor aggregate is:

$$
L_{t}=\left(b\left(L_{t}^{u}\right)^{\frac{\epsilon_{L}-1}{\epsilon_{L}}}+(1-b)\left(L_{t}^{f}\right)^{\frac{\epsilon_{L}-1}{\epsilon_{L}}}\right)^{\frac{\epsilon_{L}}{\epsilon_{L}-1}}
$$

First order conditions:

$$
\begin{gathered}
P_{t}^{I} A_{I, t} \alpha\left(K_{t}\right)^{\alpha-1}\left(L_{t}\right)^{1-\alpha}=r_{t}^{k}, \\
P_{t}^{I} A_{I, t}(1-\alpha)\left(K_{t}\right)^{\alpha}\left(L_{t}\right)^{-\alpha+\frac{1}{\epsilon_{L}}}\left(\chi L_{t}^{u}\right)^{\frac{-1}{\epsilon_{L}}} b \chi=\left(1+\tau^{s}\right) W_{t}^{u}, \\
P_{t}^{I} A_{I, t}(1-\alpha)\left(K_{t}\right)^{\alpha}\left(L_{t}\right)^{-\alpha+\frac{1}{\epsilon_{L}}}\left(\left(L_{t}^{f}+L_{t}^{i}\right)^{\frac{-1}{\epsilon_{L}}}=\left(1+\tau^{s}\right) W_{t}^{f},\right. \\
\left(1+\tau^{s}\right) W_{t}^{f}=W_{t}^{i}+\tau^{s} W_{t}^{\min }+s p W_{t}^{\min } .
\end{gathered}
$$

TFP process is:

$$
\ln \left(A_{t}\right)-\ln (\bar{A})=\rho_{A}\left(\ln \left(A_{t-1}\right)-\ln (\bar{A})\right)+\epsilon_{A}
$$

\section{Aside: Condition for Existence of Both Formal and Informal Employment}

As household derives additional disutility from working informally, it will supply labor to both formal and informal markets if:

$$
W_{t}^{i}-\tau^{h} W_{t}^{\min }>\left(1-\tau^{h}\right) W_{t}^{f} .
$$


Since formal and informal skilled labor is indistinguishable in production, the expected costs of both for the output producer are equal:

$$
W_{t}^{i}+\tau^{s} W_{t}^{\min }+s p W_{t}^{\min }=\left(1+\tau^{s}\right) W_{t}^{f} .
$$

The above two statements hold for the $W_{t}^{f}>W_{t}^{\text {min }}$ whenever:

$$
s p<\left(\tau^{s}+\tau^{h}\right)\left(\frac{W_{t}^{f}}{W_{t}^{\min }}-1\right)
$$

\section{Final Goods Producers}

Technology:

$$
Y_{F, t}=Y_{I, t}
$$

Stochastic discount factor:

$$
Q_{t, t+1}=E_{t}\left(\beta \frac{c_{r, t+1}^{-\sigma}}{c_{r, t}^{-\sigma}} \frac{1}{\pi_{t+1}}\right)
$$

First order condition:

$$
\begin{gathered}
Y_{F, t}\left(-\epsilon\left(P_{t}^{\star}\right)^{-\epsilon-1}\left(\left(1-\tau^{c}\right) P_{t}^{\star}-P_{t}^{I}-\frac{\Phi}{2}\left(\frac{P_{t}^{\star} \pi_{t}}{P_{t-1}^{\star}}-\pi_{s S}\right)^{2}\right)+\right. \\
\left.+\left(P_{t}^{\star}\right)^{-\epsilon}\left(\left(1-\tau^{c}\right)-\frac{\Phi \pi_{t}}{P_{t-1}^{\star}}\left(\frac{P_{t}^{\star} \pi_{t}}{P_{t-1}^{\star}}-\pi_{s s}\right)\right)\right)+ \\
+Q_{t, t+1} Y_{F, t+1} \Phi\left(P_{t+1}^{\star}\right)^{-\epsilon} \pi_{t+1}^{2} P_{t+1}^{\star}\left(\frac{P_{t+1}^{\star} \pi_{t+1}}{P_{t}^{\star}}-\pi_{s S}\right) \frac{1}{\left(P_{t}^{\star}\right)^{2}}=0 . \\
P_{t}^{\star}=1 .
\end{gathered}
$$

Dividends:

$$
D_{t}=\left(1-\tau_{c}\right) Y_{F, t}-P_{t}^{I} Y_{I, t}-\frac{\Phi}{2}\left(\frac{P_{t}(i)}{P_{t-1}(i)}-\pi_{S S}\right)^{2} Y_{F, t}
$$

\section{Fiscal Authority}

$$
G_{t}=\left(\tau_{s}+\tau_{h}\right)\left(W_{t}^{u} L_{t}^{u}+W_{t}^{f} L_{t}^{f}+W_{t}^{\min } L_{t}^{i}\right)+\tau_{c} P_{t} Y_{F, t}+\operatorname{sp} W_{t}^{\min } L_{t}^{i}
$$

Minimum Wage Process

$$
\ln \left(W_{t}^{\min }\right)-\ln \left(W_{s s}^{\min }\right)=\rho_{W}\left(\ln \left(W_{t-1}^{\min }\right)-\ln \left(W_{s s}^{\min }\right)\right)+\rho_{\pi W}\left(\ln \left(\pi_{t}\right)-\ln \left(\pi_{s s}\right)\right)+\epsilon_{W} .
$$

Central Bank

$$
\begin{gathered}
\ln \left(R_{t}\right)-\ln \left(R_{S S}\right)=\left(1-\rho_{R}\right)\left(\rho_{\pi}\left(\ln \left(\pi_{t}\right)-\ln \left(\pi_{s S}\right)\right)+\right. \\
\left.+\rho_{Y}\left(\ln \left(Y_{F, t}\right)-\ln \left(Y_{F, s S}\right)\right)\right)+\rho_{R}\left(\ln \left(R_{t-1}\right)-\ln \left(R_{S S}\right)\right)+\epsilon_{R} .
\end{gathered}
$$

\section{Markets Clearing}

$$
\begin{gathered}
(1-\gamma) k_{r, t-1}=K_{t}, \\
n_{n, t}^{u}=n_{r, t}^{u}=L_{t}^{u}, \\
\gamma n_{n, t}^{f}+(1-\gamma) n_{r, t}^{f}=L_{t}^{f}, \\
\gamma n_{n, t}^{i}+(1-\gamma) n_{r, t}^{i}=L_{t}^{i}, \\
Y_{I, t}=Y_{F, t}, \\
Y_{F, t}=\gamma c_{n, t}+(1-\gamma) c_{r, t}+G_{t}+(1-\gamma)\left(k_{r, t}-(1-\delta) k_{r, t-1}+\xi_{k, t}\left(k_{t}, k_{t-1}\right)\right)+ \\
+\int_{0}^{1} \xi_{p, t} Y_{F, t}(i) d i \\
(1-\gamma) D_{r, t}=D_{t} .
\end{gathered}
$$




\section{APPENDIX A2. LOG-LINEARIZED MODEL}

\section{Ricardian Households}

Budget constraint:

$$
\begin{gathered}
\frac{C r}{Y} c_{t}^{r}+\frac{K}{Y} k_{t}^{r}-(1-\delta) \frac{K}{Y} k_{t-1}^{r}-r^{k} \frac{K}{Y} k_{t-1}^{r}= \\
=\left(1-\tau_{h}\right) \frac{\operatorname{Lrf}}{L f} \frac{I F}{Y}\left(w_{t}^{f}+n_{r, t}^{f}\right)+\left(1-\tau_{h}\right) \frac{L r u}{L u} \frac{I U}{Y}\left(w_{t}^{\min }+n_{r, t}^{u}\right)+ \\
+\frac{\operatorname{Lri}}{\operatorname{Li}} \frac{I I}{Y}\left(w_{t}^{i}+n_{r, t}^{i}\right)-\tau_{h} \frac{\operatorname{Lri}}{L i} \frac{I I}{Y} \frac{W^{\min }}{W^{i}}\left(w_{t}^{\min }+n_{r, t}^{i}\right)+r^{k} \frac{K}{Y} r_{t}^{k}+\frac{D}{Y} d_{t}^{r} .
\end{gathered}
$$

First order conditions:

$$
\begin{aligned}
& \phi\left(\frac{\operatorname{Lrf}}{\operatorname{Lrf}+\operatorname{Lri}} n_{r, t}^{f}+\frac{\operatorname{Lri}}{\operatorname{Lrf}+\operatorname{Lri}} n_{r, t}^{i}\right)=-\sigma c_{t}^{r}+w_{t}^{f}, \\
& \phi^{i} n_{r, t}^{i}=-\sigma c_{t}^{r}+\frac{W i}{W d} w_{t}^{i}-\tau_{h} \frac{W \min }{W d} w_{t}^{\min }-\left(1-\tau_{h}\right) \frac{W f}{W d} w_{t}^{f}, \\
& \pi_{t+1}-\sigma c_{t}^{r}=-\sigma c_{t+1}^{r}+r_{t}, \\
& (1+\beta) \frac{\psi}{\delta} k_{t}^{r}-\frac{\psi}{\delta} k_{t-1}^{r}-\left(\beta \frac{\psi}{\delta}\right) k_{t+1}^{r}-\beta\left(\left(\frac{1}{\beta}+\delta-1\right) r_{t+1}^{k}+\sigma c_{t+1}^{r}-\sigma c_{t}^{r}=0 .\right.
\end{aligned}
$$

\section{Non-Ricardian Households}

Budget constraint:

$$
\begin{aligned}
\frac{C n}{Y} c_{t}^{n}= & \left(1-\tau_{h}\right) \frac{\operatorname{Lnf}}{L f} \frac{I F}{Y}\left(w_{t}^{f}+n_{n, t}^{f}\right)+\left(1-\tau_{h}\right) \frac{L n u}{L u} \frac{I U}{Y}\left(w_{t}^{\min }+n_{n, t}^{u}\right)+ \\
& +\frac{L n i}{L i} \frac{I I}{Y}\left(w_{t}^{i}+n_{n, t}^{i}\right)-\tau_{h} \frac{L n i}{L i} \frac{I I}{Y} \frac{W^{\text {min }}}{W^{i}}\left(w_{t}^{\text {min }}+n_{n, t}^{i}\right) .
\end{aligned}
$$

First order conditions:

$$
\begin{gathered}
\phi\left(\frac{\operatorname{Lnf}}{\operatorname{Lnf}+\operatorname{Lni}} n_{n, t}^{f}+\frac{\operatorname{Lni}}{\operatorname{Lnf}+\operatorname{Lni}} n_{n, t}^{i}\right)=-\sigma c_{t}^{n}+w_{t}^{f} \\
\phi^{i} n_{n, t}^{i}=-\sigma c_{t}^{n}+\frac{W i}{W d} w_{t}^{i}-\tau_{h} \frac{W m i n}{W d} w_{t}^{\min }-\left(1-\tau_{h}\right) \frac{W f}{W d} w_{t}^{f} .
\end{gathered}
$$

\section{Intermediate Goods Producers}

Technology is:

$$
y_{t}=a_{t}^{i}+\alpha k_{t}+(1-\alpha) l_{t}
$$

Labor aggregate is:

$$
\left(b+(1-b)\left(\frac{L f+L i}{L u}\right)^{\frac{\epsilon_{l}-1}{\epsilon_{l}}}\right) l_{t}=b l_{t}^{u}+(1-b)\left(\frac{L f+L i}{L u}\right)^{-\frac{1}{\epsilon_{l}}}\left(\frac{L f}{L u} l_{t}^{f}+\frac{L i}{L u} l_{t}^{i}\right) .
$$

First order conditions:

$$
\begin{gathered}
p_{t}^{I}+a_{t}^{I}+(\alpha-1) k_{t}+(1-\alpha) l_{t}=r_{t}^{k} \\
p_{t}^{I}+a_{t}^{I}+\alpha k_{t}+\left(\frac{1}{\epsilon_{l}}-\alpha\right) l_{t}+\left(-\frac{1}{\epsilon_{l}}\right) l_{t}^{u}=W_{t}^{\text {min }} \\
p_{t}^{I}+a_{t}^{I}+\alpha k_{t}+\left(\frac{1}{\epsilon_{l}}-\alpha\right) l_{t}+\left(-\frac{1}{\epsilon_{l}}\right)\left(\frac{L f}{L f+L i} l_{t}^{f}+\frac{L i}{L f+L i} l_{t}^{i}\right)=w_{t}^{f}, \\
\left(1+\tau_{s}\right) \frac{W f}{W \min } w_{t}^{f}=\frac{W i}{W \min } w_{t}^{i}+\left(\tau_{s}+s p\right) w_{t}^{\text {min }} .
\end{gathered}
$$

TFP process is:

$$
a_{t}^{I}=\rho_{A} a_{t-1}^{I}+\epsilon_{A}
$$




\section{Final Goods Producers}

First order condition:

$$
\pi_{t}=\frac{(\epsilon-1)\left(1-\tau_{c}\right)}{\Phi \pi_{S S}^{2}} p_{t}^{I}+\beta \pi_{t+1} .
$$

Dividends:

$$
d_{t}=y_{t}-(\epsilon-1) p_{t}^{I}
$$

\section{Fiscal Authority}

$$
\begin{gathered}
\frac{T R}{Y} g_{t}=\left(\tau_{h}+\tau_{s}\right) \frac{I U}{Y}\left(w_{t}^{\text {min }}+l_{t}^{u}\right)+\left(\tau_{h}+\tau_{s}\right) \frac{I F}{Y}\left(w_{t}^{f}+l_{t}^{f}\right)+ \\
+\left(\tau_{h}+\tau_{s}\right) \frac{I I}{Y} \frac{W m i n}{W i}\left(w_{t}^{\text {min }}+l_{t}^{i}\right)+\tau_{c} y_{t}+p s \frac{I I}{Y} \frac{W m i n}{W i}\left(w_{t}^{\text {min }}+l_{t}^{i}\right) .
\end{gathered}
$$

Minimum Wage Process

$$
w_{t}^{\min }=\rho_{W} w_{t-1}^{\min }+\rho_{\pi W} \pi_{t}+\epsilon_{W}
$$

\section{Central Bank}

$$
r_{t}=\left(1-\rho_{R}\right)\left(\rho_{\pi} \pi_{t}+\rho_{Y} y_{t}\right)+\rho_{R} r_{t-1}+\epsilon_{R}
$$

Markets Clearing

$$
\begin{gathered}
k_{t}=k_{t-1}^{r}, \\
d_{t}=d_{t}^{r}, \\
n_{n, t}^{u}=n_{r, t}^{u}=l_{t}^{u}, \\
\frac{L n i}{L i} n_{n, t}^{i}+\frac{L r i}{L i} n_{r, t}^{i}=l_{t}^{i}, \\
\frac{L n f}{L f} n_{n, t}^{f}+\frac{L r f}{L i f} n_{r, t}^{f}=l_{t}^{f} .
\end{gathered}
$$

Total Consumption

$$
\left(\frac{C n}{Y}+\frac{C r}{Y}\right) c_{t}=\frac{C n}{Y} c_{t}^{n}+\frac{C r}{Y} c_{t}^{r}
$$

Total Investment

$$
\delta i_{t}=k_{t}^{r}-(1-\delta) k_{t-1}^{r} .
$$

Total Labor

$$
l t_{t}=\frac{L u}{L t} l_{t}^{u}+\frac{L u f}{L t} l_{t}^{f}+\frac{L i}{L t} l_{t}^{i} .
$$




\section{APPENDIX A3. STEADY-STATE RATIOS}

Reported minimum wage labor to total labor:

$$
\frac{L \min }{L t}=S H \min
$$

Informal labor to reported minimum wage labor:

$$
\frac{L i}{\operatorname{Lmin}}=\operatorname{SHinf}
$$

Minimum wage to average wage:

$$
\frac{W \min }{W a}=S H w a g \text {. }
$$

Minimum wage to formal wage:

$$
\frac{W \min }{W f}=\frac{1-\text { SHmin }}{\frac{1}{\text { SHwag }}-\text { SHmin }} .
$$

Non-Ricardian low-skilled labor to total unskilled labor:

$$
\frac{L n u}{L u}=\text { SHnon } .
$$

Non-Ricardian formal labor to total formal labor:

$$
\frac{\operatorname{Lnf}}{L f}=\text { SHnon } .
$$

Non-Ricardian informal labor to total informal labor:

$$
\frac{L n i}{L i}=\text { SHnon }
$$

Capital rental rate:

$$
r_{k}=\delta-1+1 / \beta \text {. }
$$

Capital to output ratio:

$$
\frac{K}{Y}=\frac{\alpha}{r_{k}} .
$$

Formal labor to total labor:

$$
\frac{L f}{L t}=1-\frac{L \min }{L t} .
$$

Informal labor to total labor:

$$
\frac{L i}{L t}=1-\frac{L i}{L \min } \frac{L m i n}{L t}
$$

Low-skilled labor to total labor:

$$
\frac{L u}{L t}=1-\left(1-\frac{L i}{L m i n}\right) \frac{L \min }{L t} .
$$

Labor aggregate to low-skilled labor:

$$
\frac{L}{L u}=\left(b+(1-b)\left(\frac{L f+L i}{L u}\right)^{\frac{\epsilon_{l}-1}{\epsilon_{l}}}\right)^{\frac{\epsilon_{l}}{\epsilon_{l}-1}} .
$$

Informal wage to minimum wage:

$$
\frac{W i}{W \min }=\frac{W f}{W \min }\left(1+\tau_{s}\right)-\left(\tau_{s}+p s\right) .
$$

Ricardian low-skilled labor to total low-skilled labor:

$$
\frac{L r u}{L u}=1-\frac{L n u}{L u} .
$$

Ricardian formal labor to total formal labor:

$$
\frac{L r f}{L f}=1-\frac{L n f}{L f}
$$


Ricardian informal labor to total informal labor:

$$
\frac{L r i}{L i}=1-\frac{L n i}{L i}
$$

Non-Ricardian informal labor to total labor:

$$
\frac{L n i}{L t}=\frac{L n i}{L i} \frac{L i}{L t}
$$

Ricardian informal labor to total labor:

$$
\frac{L r i}{L t}=\frac{L r i}{L i} \frac{L i}{L t}
$$

Non-Ricardian formal labor to total labor:

$$
\frac{L n f}{L t}=\frac{L n f}{L f} \frac{L f}{L t} .
$$

Ricardian formal labor to total labor:

$$
\frac{L r f}{L t}=\frac{L r f}{L f} \frac{L f}{L t} .
$$

Low-skilled labor before tax income to output:

$$
\frac{I U}{Y}=(1-\alpha) b\left(\frac{L u}{L}\right)^{1-\frac{1}{\epsilon_{l}}} /\left(1+\tau_{s}\right) .
$$

Formal labor before tax income to output:

$$
\frac{I F}{Y}=\frac{I U}{Y} \frac{L f}{L u} \frac{W f}{W \min } .
$$

Informal labor before tax income to output:

$$
\frac{I I}{Y}=\frac{I U}{Y} \frac{L i}{L u} \frac{W i}{W \min } .
$$

Tax revenue to output:

$$
\frac{T R}{Y}=\left(\tau_{h}+\tau_{s}\right)\left(\frac{I U}{Y}+\frac{I F}{Y}+\frac{I I}{Y} \frac{W \min }{W i}\right)+\tau_{c}+p s \frac{I I}{Y} \frac{W m i n}{W i} .
$$

Wage difference to minimum wage:

$$
\frac{W d}{W \min }=\frac{W i}{W \min }-\tau_{h}-\left(1-\tau_{h}\right) \frac{W f}{W \min } .
$$

Non-Ricardian consumption to output:

$$
\frac{C n}{Y}=\left(1-\tau_{h}\right) \frac{L n u}{L u} \frac{I U}{Y}+\left(1-\tau_{h}\right) \frac{L n f}{L f} \frac{I F}{Y}+\frac{L n i}{L i} \frac{I I}{Y}-\tau_{h} \frac{L n i}{L i} \frac{I I}{Y} \frac{W m i n}{W i} .
$$

Ricardian consumption to output:

$$
\frac{C r}{Y}=1-\delta * \frac{K}{Y}-\frac{T R}{Y}-\frac{C n}{Y}
$$

Dividends:

$$
\frac{D}{Y}=\left(1-\tau_{c}\right) / \epsilon
$$

Low-skilled labor share parameter:

$$
b=\frac{1}{1+\left(\frac{L u}{L f+L i}\right)^{-\frac{1}{\epsilon_{l}}} \frac{W f}{W \min }} .
$$




\section{APPENDIX B. TABLES}

Table B1. Calibrated Parameters

\begin{tabular}{|c|c|c|}
\hline Parameter Name & Description & Value \\
\hline$\sigma$ & Relative risk aversion coefficient & 1.000 \\
\hline$\pi_{s s}$ & Steady-State Inflation & 1.034 \\
\hline$\beta$ & Utility time discount factor & 0.996 \\
\hline$\varepsilon$ & Elasticity of substitution between different consumer goods & 5.617 \\
\hline$\alpha$ & Capital income share & 0.268 \\
\hline SHwag & Minimum wage to average wage ratio & 0.330 \\
\hline SHnon & Share of non-Ricaridan households & 0.350 \\
\hline$\varepsilon_{L}$ & Elasticity of substitution between high- and low-skilled labor & 2.000 \\
\hline$\rho_{R}$ & Interest rate rule autocorrelation parameter & 0.928 \\
\hline$\rho_{\pi}$ & Interest rate rule response to inflation & 1.668 \\
\hline$\rho_{Y}$ & Interest rate rule response to output gap & 0.144 \\
\hline$\sigma_{\varepsilon R}$ & Standard deviation of monetary shock & 0.129 \\
\hline$\rho_{W}$ & Minimum wage autocorrelation & 0.944 \\
\hline$\rho_{\pi W}$ & Minimum wage response to inflation & -1.542 \\
\hline$\sigma_{\varepsilon W}$ & Standard deviation of minimum wage shock & 0.209 \\
\hline$\delta$ & Capital depreciation rate & 0.008 \\
\hline$p$ & Probability of being audited & 0.006 \\
\hline$s$ & Surcharge over minimum wage in case of the detection of underreporting & 7.500 \\
\hline$\tau_{s}$ & Social security tax rate & 0.180 \\
\hline$\tau_{h}$ & Income tax rate & 0.220 \\
\hline$\tau_{c}$ & VAT rate & 0.167 \\
\hline SHmin & Steady state of workers reporting minimum wage & 0.331 \\
\hline SHinf & Steady-state share of underreporting of workers reporting minimum wage & 0.690 \\
\hline
\end{tabular}

Table B2. Estimated Parameters, Priors and Posteriors

\begin{tabular}{lcccccc}
\hline $\begin{array}{l}\text { Parameter } \\
\text { Name }\end{array}$ & Description & $\begin{array}{c}\text { Prior } \\
\text { form }\end{array}$ & $\begin{array}{c}\text { Prior } \\
\text { mean }\end{array}$ & $\begin{array}{c}\text { Prior } \\
\text { st. dev. }\end{array}$ & $\begin{array}{c}\text { Post. } \\
\text { mean }\end{array}$ & $\begin{array}{c}\text { Post. 90\% } \\
\text { HPD interval }\end{array}$ \\
\hline$\rho_{A}$ & TFP autocorrelation & beta & 0.850 & 0.100 & 0.827 & {$[0.697,0.950]$} \\
$\sigma_{A}$ & TFP shock std. dev. & invg & 0.005 & 0.025 & 0.0892 & {$[0.064,0.115]$} \\
$\psi$ & Capital adjustment cost & gamma & 1.000 & 0.500 & 1.120 & {$[0.713,1.466]$} \\
$\Phi$ & $\begin{array}{l}\text { Price adjustment cost } \\
\text { Inverse Frich elasticity } \\
\text { of labor supply }\end{array}$ & gamma & 20.000 & 10.000 & 40.237 & {$[24.313,58.735]$} \\
$\varphi^{i}$ & $\begin{array}{l}\text { Inverse Frich elasticity } \\
\text { of informal labor supply }\end{array}$ & gamma & 1.000 & 0.100 & 1.007 & {$[0.865,1.175]$} \\
& & & 0.500 & 0.823 & {$[0.438,1.287]$} \\
\hline
\end{tabular}




\section{APPENDIX C1. MAIN RESULTS}

Figure C1.1. Impulse Responses to the Minimum Wage Shock of 1st. dev. (Depending on the Share of Underreporting)
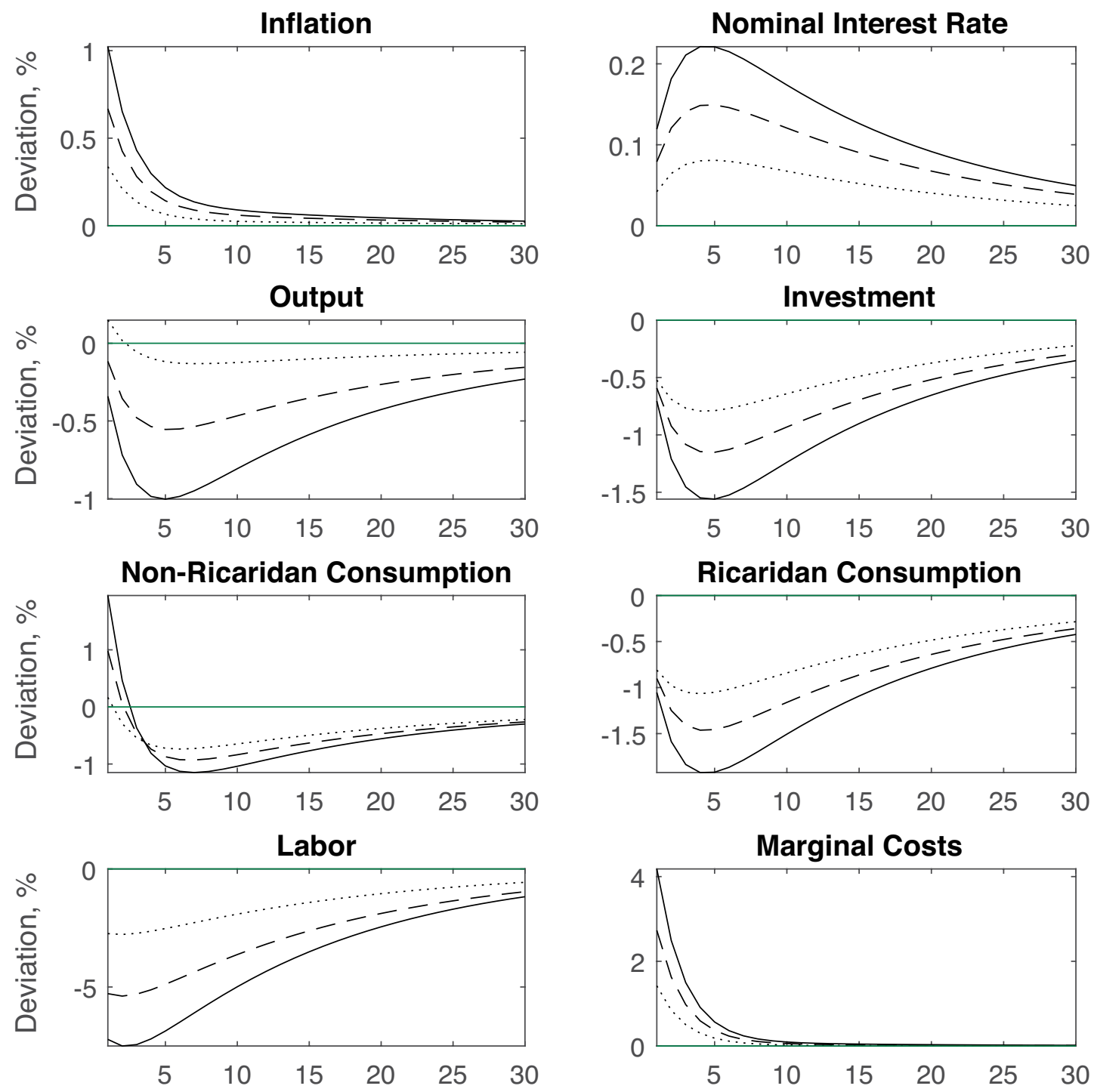

0.1 Underreporting ---0.4 Underreporting 0.69 Underreporting 
Figure C1.2. Impact Response to Minimum Wage Shock of 1st. dev.
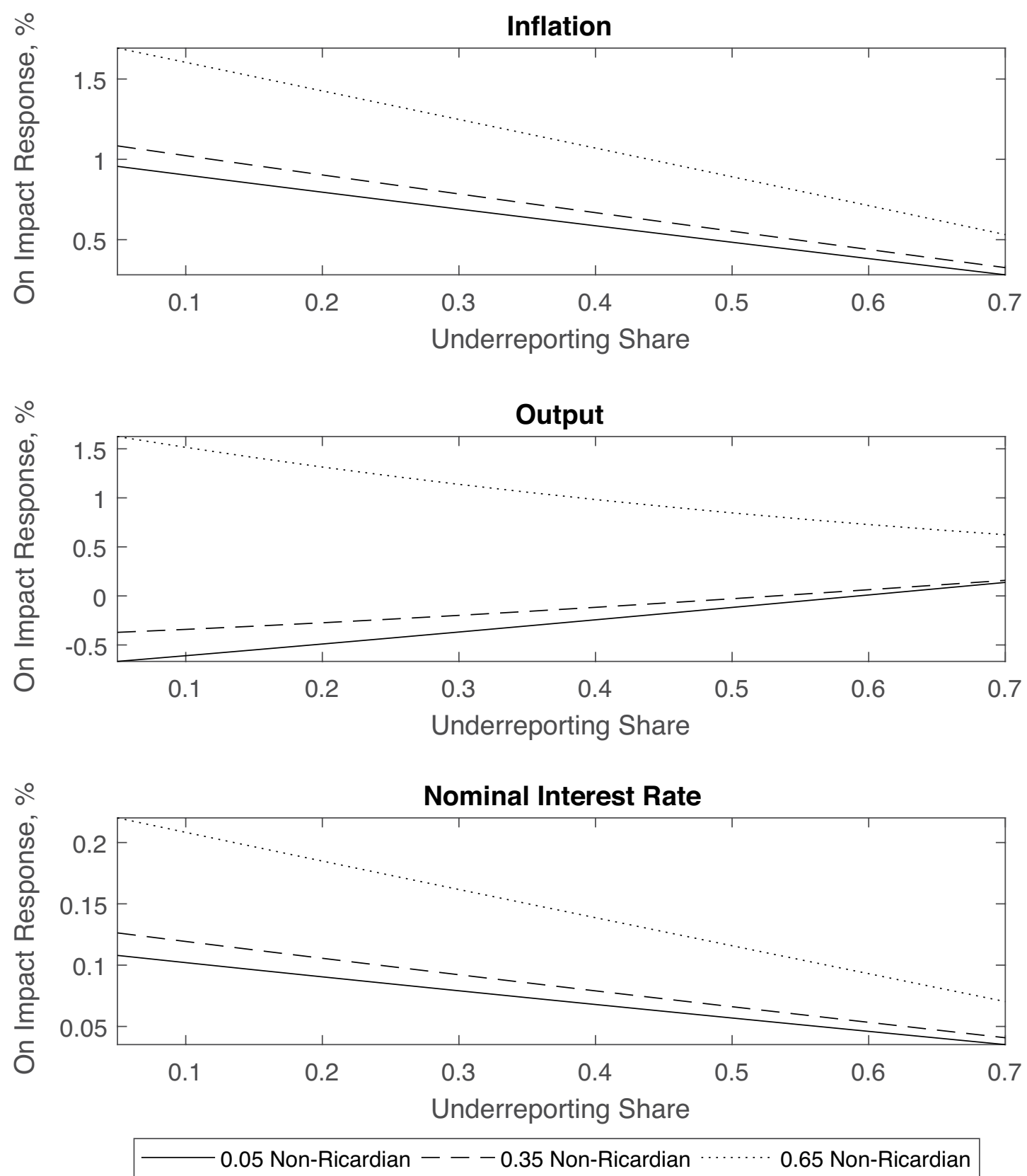
Figure C1.3. Impulse Responses to a Minimum Wage Shock of 1st. dev. (Depending on Non-Ricardian Households Share)
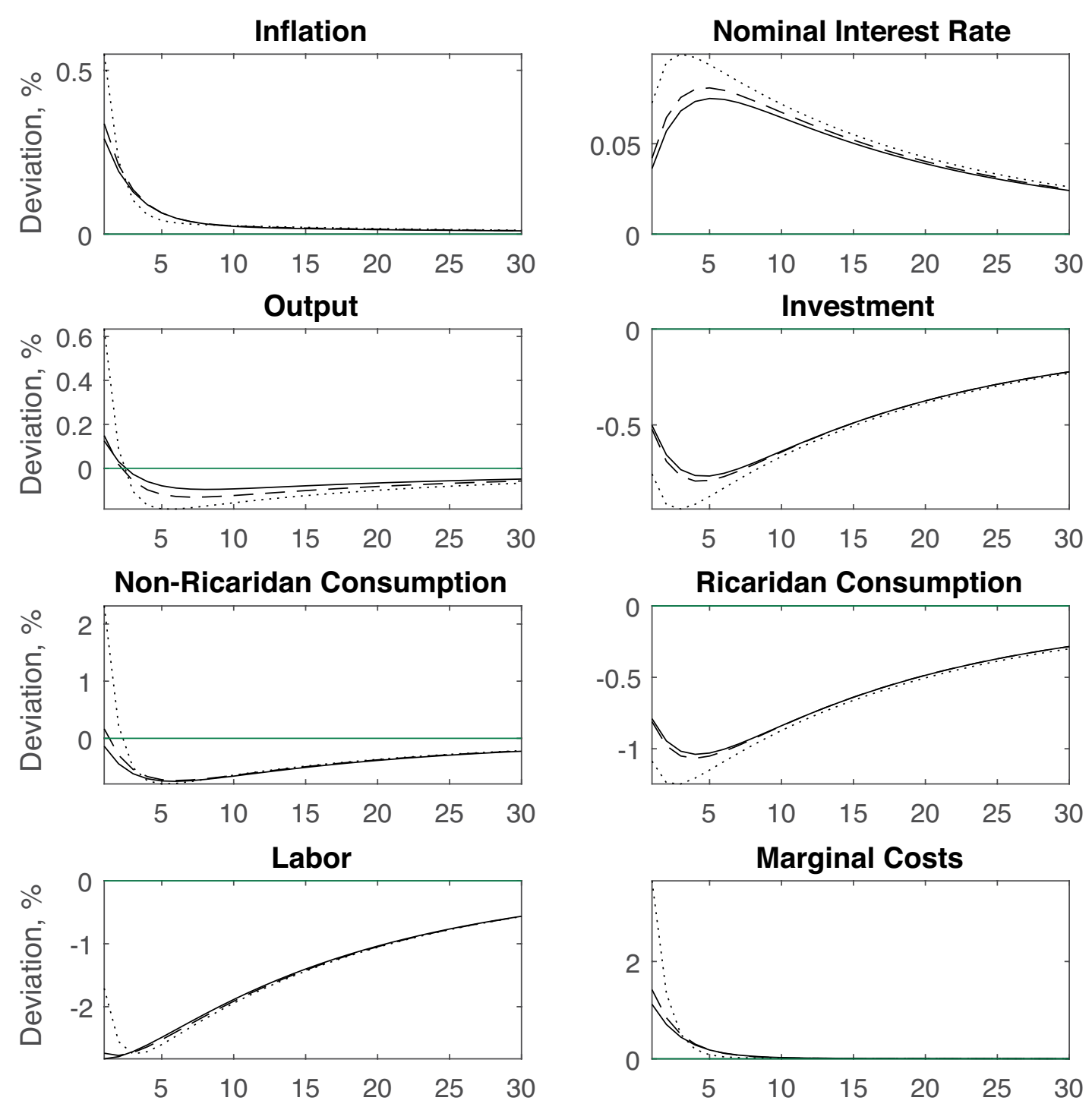

0.05 Non-Ricardian ---0.35 Non-Ricardian $\cdots \cdots \cdots \cdot 0.65$ Non-Ricardian 
Figure C1.4. Impact Response to Minimum Wage Shock of 1st. dev.
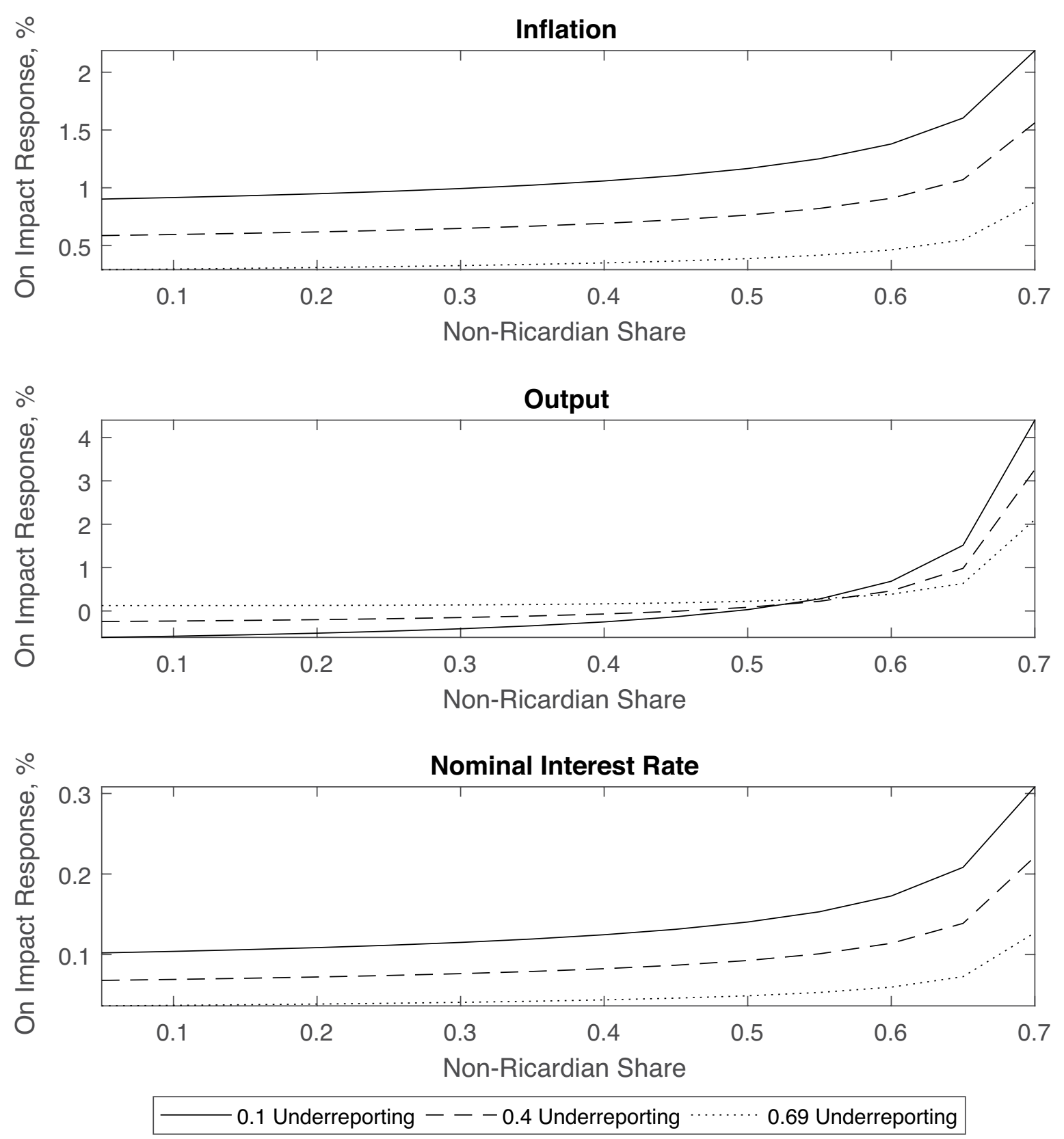


\section{APPENDIX C2. IMPULSE RESPONSES}

Figure C2.1. TFP Shock of 1st. dev.

(Depending on Underreporting Share)
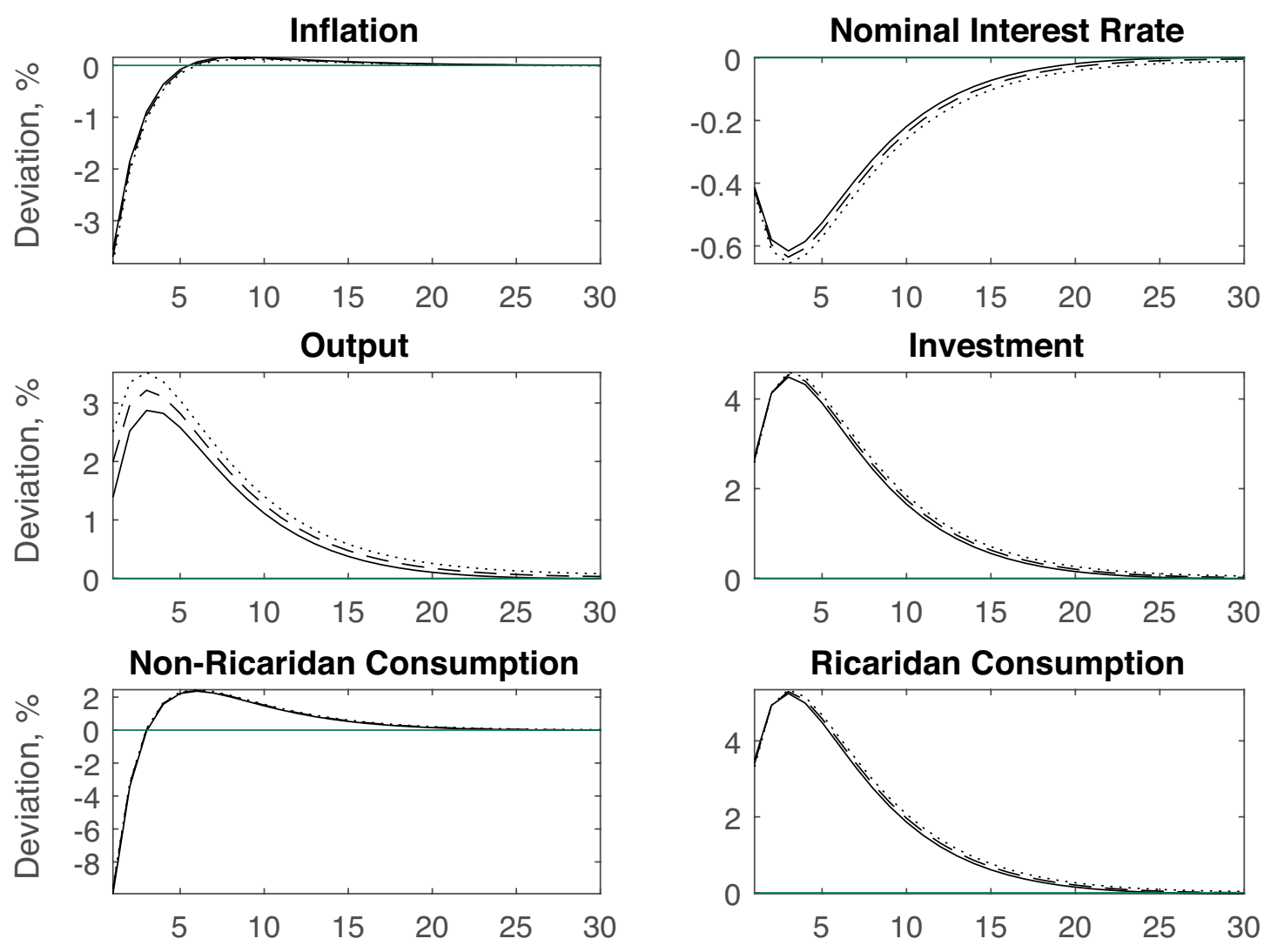

Ricaridan Consumption
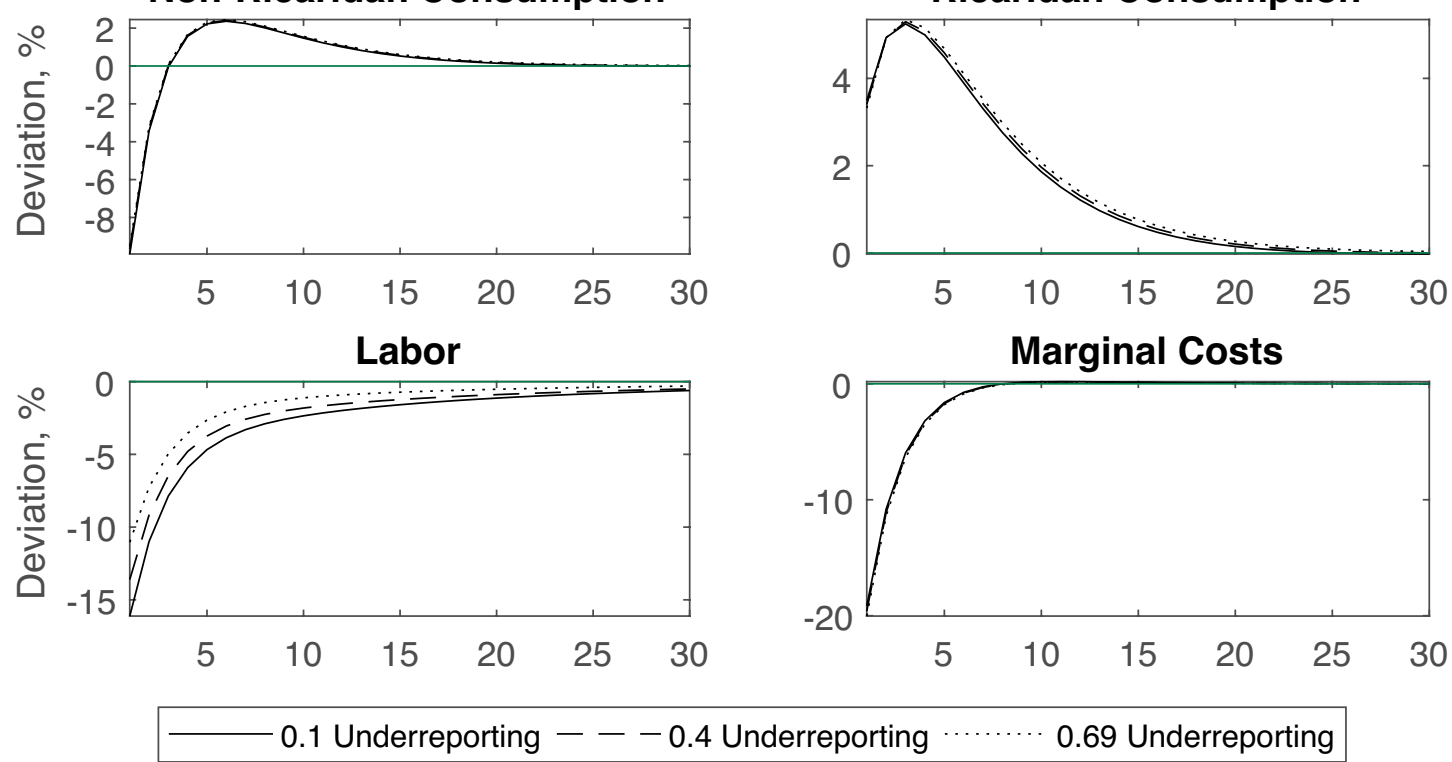
Figure C2.2. Monetary Shock of 1st. dev.

(Depending on Underreporting Share)
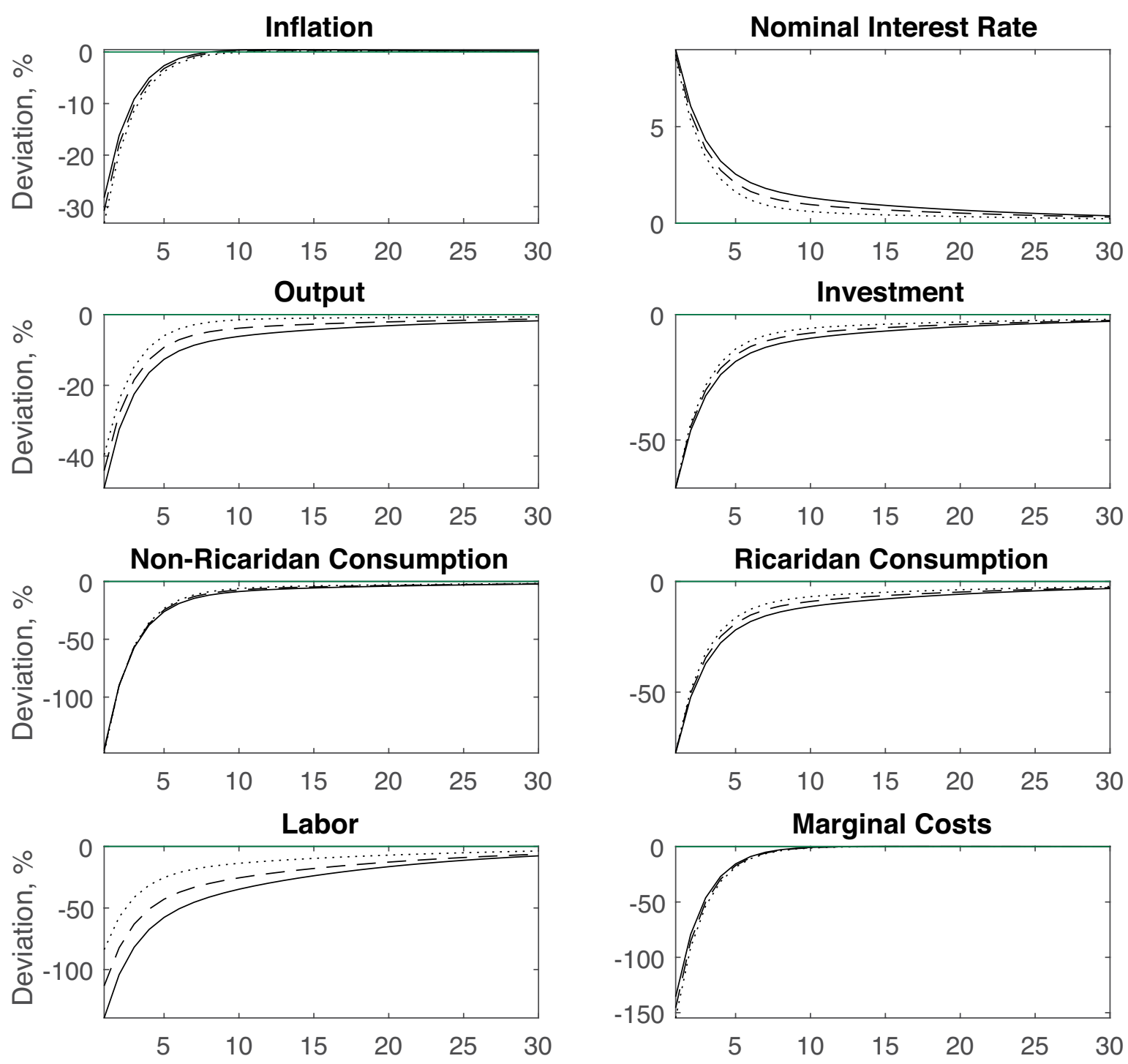

0.1 Underreporting --0.4 Underreporting

0.69 Underreporting 
Figure C2.3. TFP Shock of 1st. dev.

(Depending on Non-Ricardian Share)
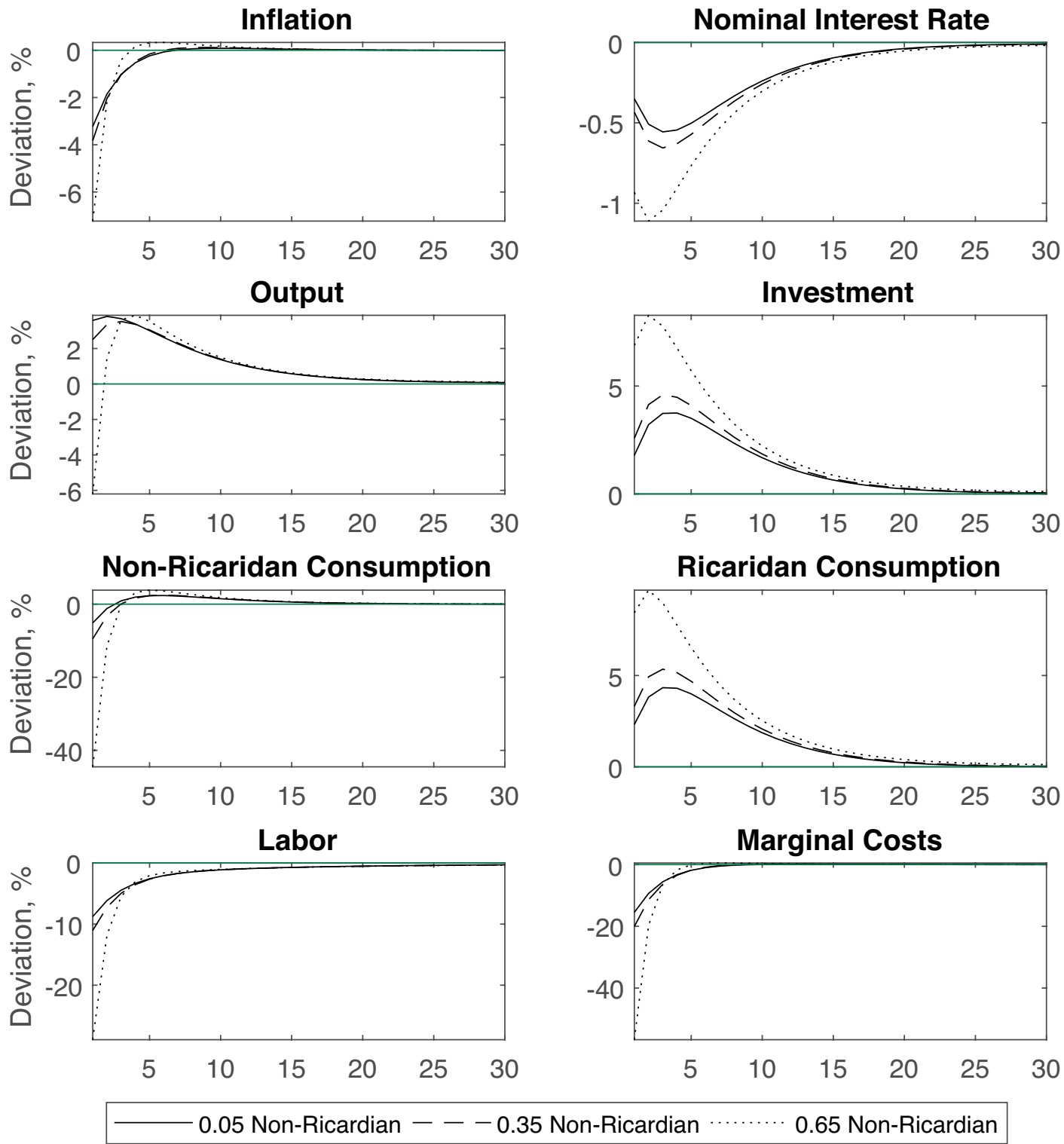
Figure C2.4. Monetary Shock of 1st. dev.

(Depending on Non-Ricardian Share)
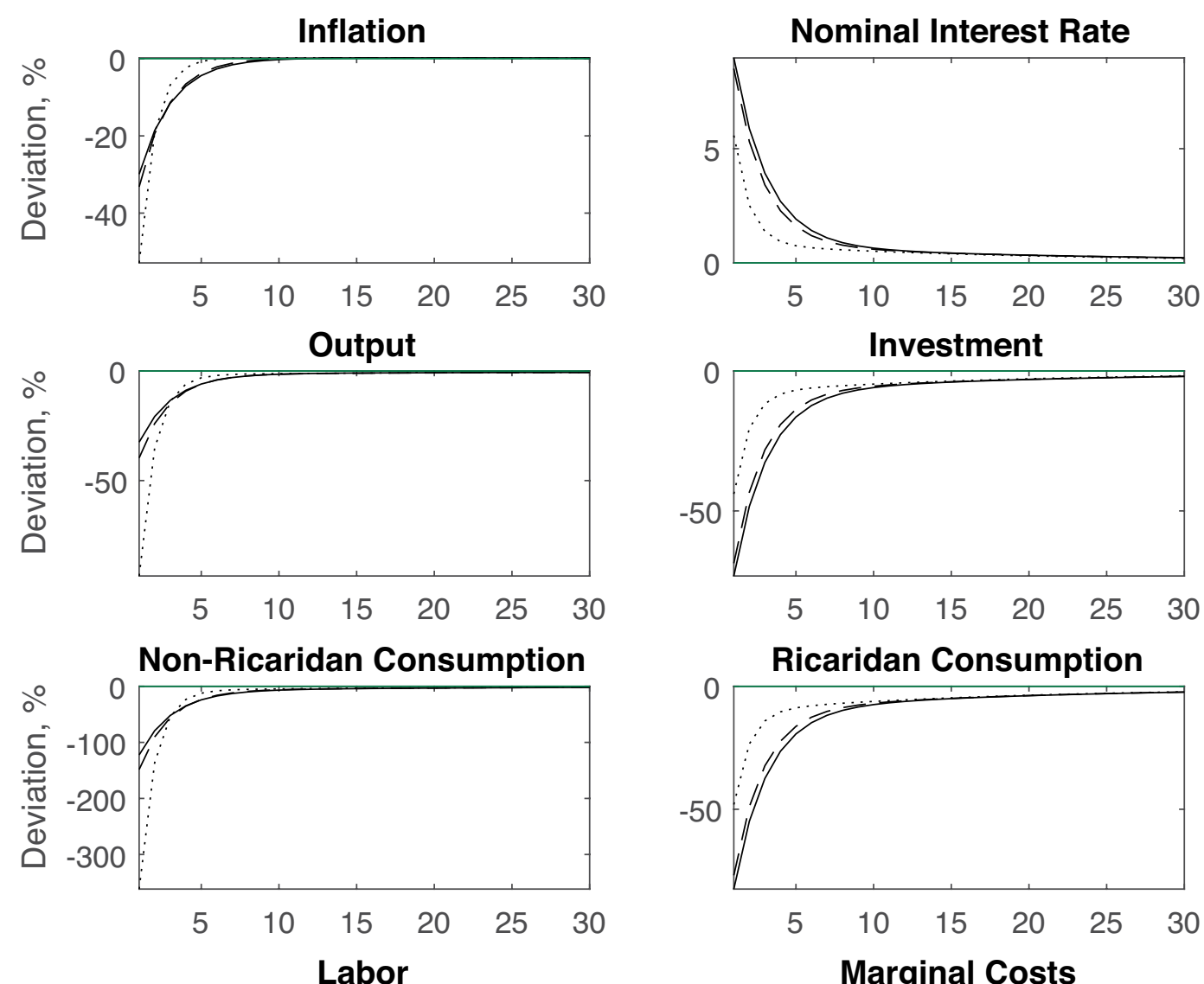

Ricaridan Consumption
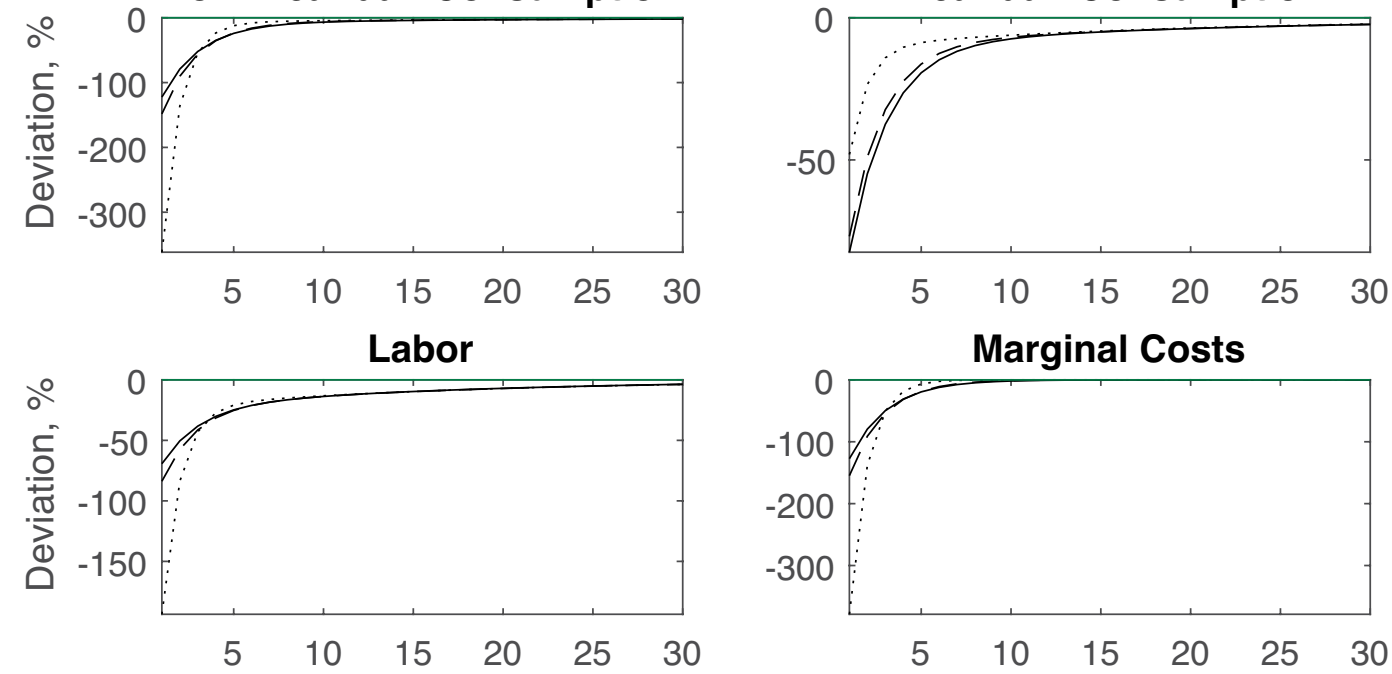

0.05 Non-Ricardian --0.35 Non-Ricardian

0.65 Non-Ricardian 